\title{
Insights into the Role of Estrogen Receptor $\beta$ in Triple-Negative Breast Cancer
}

\author{
Assunta Sellitto ${ }^{1,+}{ }^{\oplus}$, Ylenia D’Agostino ${ }^{1,+}{ }^{\dagger}$ Elena Alexandrova ${ }^{1} \mathbb{C}$, Jessica Lamberti ${ }^{1}$, \\ Giovanni Pecoraro ${ }^{1}$, Domenico Memoli ${ }^{1}{ }^{\circledR}$, Domenico Rocco ${ }^{1}$, Elena Coviello ${ }^{2}$, \\ Giorgio Giurato ${ }^{1}\left(\mathbb{D}\right.$, Giovanni Nassa ${ }^{1}$ (D), Roberta Tarallo ${ }^{1} \mathbb{D}$, Alessandro Weisz ${ }^{1,3, *(D)}$ \\ and Francesca Rizzo 1,3,*(D) \\ 1 Laboratory of Molecular Medicine and Genomics, Department of Medicine, Surgery and Dentistry \\ 'Scuola Medica Salernitana', University of Salerno, 84081 Baronissi, Italy; assellitto@unisa.it (A.S.); \\ ydagostino@unisa.it (Y.D.); ealexandrova@unisa.it (E.A.); jlamberti@unisa.it (J.L.); gipecoraro@unisa.it (G.P.); \\ dmemoli@unisa.it (D.M.); drocco@unisa.it (D.R.); ggiurato@unisa.it (G.G.); gnassa@unisa.it (G.N.); \\ rtarallo@unisa.it (R.T.) \\ 2 Genomix4Life, via S. Allende 43/L, 84081 Baronissi (SA), Italy; ecoviello@unisa.it \\ 3 CRGS (Genome Research Center for Health), University of Salerno Campus of Medicine, \\ 84081 Baronissi (SA), Italy \\ * Correspondence: aweisz@unisa.it (A.W.); frizzo@unisa.it (F.R.); Tel.: (39+)-089-965043 (A.W.); \\ Tel.: (39+)-089-965221 (F.R.) \\ + These authors contributed equally to this work.
}

Received: 10 May 2020; Accepted: 3 June 2020; Published: 5 June 2020

check for updates

\begin{abstract}
Estrogen receptors (ER $\alpha$ and $E R \beta)$ are ligand-activated transcription factors that play different roles in gene regulation and show both overlapping and specific tissue distribution patterns. $\mathrm{ER} \beta$, contrary to the oncogenic $\mathrm{ER} \alpha$, has been shown to act as an oncosuppressor in several instances. However, while the tumor-promoting actions of ER $\alpha$ are well-known, the exact role of ER $\beta$ in carcinogenesis and tumor progression is not yet fully understood. Indeed, to date, highly variable and even opposite effects have been ascribed to ER $\beta$ in cancer, including for example both proliferative and growth-inhibitory actions. Recently ER $\beta$ has been proposed as a potential target for cancer therapy, since it is expressed in a variety of breast cancers (BCs), including triple-negative ones (TNBCs). Because of the dependence of TNBCs on active cellular signaling, numerous studies have attempted to unravel the mechanism(s) behind ER $\beta$-regulated gene expression programs but the scenario has not been fully revealed. We comprehensively reviewed the current state of knowledge concerning ER $\beta$ role in TNBC biology, focusing on the different signaling pathways and cellular processes regulated by this transcription factor, as they could be useful in identifying new diagnostic and therapeutic approaches for TNBC.
\end{abstract}

Keywords: estrogen receptor $\beta$; TNBC; cancer cell metabolism; oncosuppressor

\section{Introduction}

Estrogen receptors (ERs) are ligand-activated transcription factors that mediate the effect of estrogens in the development and growth of both normal and malignant mammary tissues. Ligand-activated ERs are able to form dimers that, directly or through other proteins, bind specific estrogen response elements (EREs) in the target gene promoters and regulate their transcription [1,2].

ER alpha (ER $\alpha$ ) is the major driver of $\sim 75 \%$ of breast cancers (BC), its role altogether with the ones of its target genes have been extensively studied. ER $\alpha$ and $E R \alpha$-regulated genes represent the main targets in clinical approaches aimed to control hormonally responsive BC [3]. 
The discovery of estrogen receptor- $\beta$ (ER $\beta$ ) dates back to 1996 when this molecule was cloned for the first time from rat prostate [4]. ER $\beta$ has functions and expression patterns distinct from ER $\alpha$ and it is widely expressed in both normal and neoplastic human breast tissues $[5,6]$. In the normal mammary gland, ER $\beta$ is the most widely expressed ER, and is present in luminal epithelial cells, myoepithelial cells, and some stromal cells [5]. However, studies of ER $\beta$ knockout $(\mathrm{KO})$ in mice suggest a minor role of ER $\beta$ on the mammary gland development $[7,8]$.

The exact role of ER $\beta$ in BC is controversial. Indeed, both proliferative and anti-proliferative ER $\beta$ roles have been described $[9,10]$. This different behavior could be explained by the existence of different receptor isoforms, problems related to the use of poorly specific antibodies (Sections 3.1 and 3.2 of this review), and co-expression of ER $\beta$ binding partners and the use of different experimental approaches, such as ectopic expression and gene knockdown. Concerning this point, CRISPR/Cas genome editing technology could be a valid alternative to avoid artefacts or incidental effects.

Several coherent findings showed that ER $\beta$ expression decreases in precancerous and cancerous breast lesions [6,11-15], and is reduced or completely absent in invasive breast tumors [13,16], an event common also to other cancers such as colon, lung, ovary, and prostate $[17,18]$. Interestingly, Zhoa et al. [19] demonstrated an inverse correlation between methylation of ER $\beta$ promoter and mRNA levels, suggesting that ER $\beta$ expression is regulated by an epigenetic mechanism. Furthermore, in a very recent work, Warner et al. have reevaluated the role of ER $\beta$, using the CRISPR/Cas9 technology to create an ER $\beta$ KO mouse model in which the entire gene has been deleted. These authors observed the formation of in situ ductal cancer in the prostate and mammary gland in ER $\beta$ KO mice, and then confirming an oncosuppressive role of this receptor [20].

Differences observed in the role of ER $\beta$ are also potentially related to whether or not ER $\beta$ is expressed alone or co-expressed with ER $\alpha$. In fact, ER $\beta$ appears to oppose ER $\alpha$ actions on cell proliferation by modulating the expression of many ER $\alpha$ regulated genes [21], including microRNA genes [21,22]. Several research groups have explored the role of ER $\beta$ in ER $\alpha$ negative patient cohorts and demonstrated that ER $\beta$ expression is also associated with increased response to tamoxifen therapy $[23,24]$.

Several reviews have generally addressed the topic of ER $\beta$ function in tumorigenesis [25-29], also taking into account the possible bilateral role of ER $\beta$ in BC [10]. Various reports have shown that ER $\beta$ is expressed in a subgroup of triple negative breast cancer (TNBC), accounting for $15-30 \%$ of the tissue samples (see Section 3.3) [30-33]. Characterization of the nature and role of ER $\beta$ in TNBC is little explored, but the available data suggest that its role may be different from that observed in the presence of $E R \alpha$ [34]. In this review, we summarize what has been learned about the role of ER $\beta$ in TNBC by highlighting the pathways regulated by ER $\beta$ that could represent a valuable target for TNBC therapies.

\section{Pathological Features of TNBC}

$\mathrm{BC}$ is one of the most common women cancers and represents a serious worldwide health problem. It can be considered as a multifaceted disease including a heterogeneous group of tumors with great variety in clinical, morphological, and molecular aspects [35]. Indeed, BC comprises various subtypes that differ from each other in histopathological characteristics, biomarker profiles, predictive, and prognostic parameters [36]. Traditionally, the classification of BC has been based on histological assessment and clinical staging in order to guide patient management. However, in recent years, remarkable progress in molecular analysis has profoundly improved our knowledge about BC biology and, hence, refined the classification, too [35,37]. The major classification of BC is generally based on the expression of $\mathrm{ER} \alpha$, progesterone receptor (PR) or over-expression and/or amplification of the human epidermal growth factor receptor 2 (HER2/neu); their presence is assessed to predict prognosis as well as the potential response to endocrine treatments $[38,39]$. Nevertheless, there is a unique subset of tumors, that accounts for almost $15-20 \%$ of all BC, characterized by the lack of expression of all 
three previously indicated receptor types when assessed by immunohistochemistry (IHC) and for this reason referred to as TNBC [40].

TNBCs are known to possess a more aggressive behavior and worse disease-specific outcomes compared to ER $\alpha$-positive BCs. Although TNBC accounts for $\sim 15 \%$ of all BC cases, it is responsible for over $50 \%$ of the observed mortality [41,42]. Indeed, almost one-third of the patients with TNBC face a distant recurrence within the first $3-5$ years after diagnosis $[43,44]$. At diagnosis, patients usually present clinically positive axillary lymph node and metastatic spread to the lung, liver, and central nervous system, as well as poorer survival [45]. Given the aggressiveness of TNBC, early and accurate diagnosis of the disease is necessary for determining prognosis and allowing adequate therapy choice. Since patients affected by TNBC do not benefit from hormonal or trastuzumab-based therapies because of the lack of target receptors, to date the mainly used therapeutic approach has been surgery and cytotoxic chemotherapy, used either individually or in combination [46,47].

However, the advent of next-generation sequencing (NGS) has allowed for the dissection of TNBC biology and highlighted a number of molecular features typical of this cancer that could provide further insight into altered cellular pathways and identify novel therapeutic targets to face the disease $[48,49]$. Indeed, a better understanding of cancer biology together with morphological analyses can help the identification of different TNBC subtypes with various prognoses that can possibly be used to predict treatments response.

\section{ER $\beta$ Structure and Roles in TNBC}

\subsection{ER $\beta$ Domains and Isoforms}

The full-length ER $\beta$ (also termed ER $\beta 1$ ), encoded by the ESR2 gene, consists of eight exons and codify for a protein of 530 amino acids, which is structurally similar to $\mathrm{ER} \alpha$ and contains five distinct domains (Figure 1) [50]. The N-terminal A/B domain, alternatively known as activation function 1 (AF1) domain, is involved in ligand-independent receptor activity and comprises several amino acids that are targeted by post-translational modifications. It shares low homology with the corresponding ER $\alpha$ domain and is essential for the receptor to interact with its co-regulators [51]. The $\mathrm{C}$ domain shares 95\% identity with $\mathrm{ER} \alpha$, contains two zinc finger structures, and mediates the receptor dimerization and sequence-specific DNA binding [52]. The D domain promotes receptor nuclear translocation and is targeted by post-translational modifications that can influence ER $\beta$ activity and degradation [51]. The E domain, alternatively known as the ligand-binding domain (LBD) or activation function 2 (AF2) domain, shares 55\% similarity with ER $\alpha$ [53] and, compared to it, has a significantly smaller ligand-binding pocket that differs in the amino acid residues lining the cavity borders, which contributes to selective receptor ligands affinity [53], opening the possibility of drug therapy with ER $\beta$ selective modulators [54]. Finally, at the ER $\beta$ C-terminal end there is a short F domain whose function is still unclear and has almost no sequence homology with ER $\alpha$ [52].

Besides, multiple ER $\beta$ isoforms (Figure 1) have been described and their differential expression has been shown in BC at both RNA and the protein level [55]. Beyond the full-length ER $\beta 1$, other four $E R \beta$ splicing isoforms (ER $\beta 2 / c x, E R \beta 3, E R \beta 4$, and ER $\beta 5$ ) exist (Figure 1). These are derived mainly from alternatively splicing events involving the exon 8 , resulting in C-terminally truncated proteins that cannot bind ligands but are biologically active [56].

In $\mathrm{BC}$, apart from ER $\beta 1$, the best-studied isoform is $E R \beta 2 / c x$, which mediates proteasome-dependent degradation of $\mathrm{ER} \alpha$ [57] and its expression has been correlated with aggressive features and malignant phenotype [27,58]. ER $\beta 2 / \mathrm{cx}$ and ER $\beta 4-5$ isoforms can dimerize with ER $\beta 1$, modulating its ligand-dependent transcriptional activity [59], whereas ER $\beta 3$ expression, to date, has not been detected in cell lines and tumor specimens [60], but it seems to be expressed only in testis [61].

In TNBC patients, high levels of ER $\beta 2 / c x$ have been associated with early tumor relapse [62]. Similar behavior of this isoform has been observed also in TNBC cell lines, where ER $\beta 2 / c x$, altogether with ER $\beta 4-5$ isoforms, enhances hypoxic signaling, previously correlated to tumor aggressiveness [63]. 
The ER $\beta 4$ isoform, that is not expressed in physiological conditions [63], has been correlated with poor outcome in TNBC patients [64]. These evidences suggest that ER $\beta$ isoforms have distinct involvement in tumor development, which partially explain some contradictory results concerning ER $\beta$ role. However, their functions are not fully understood and further clarification is needed.

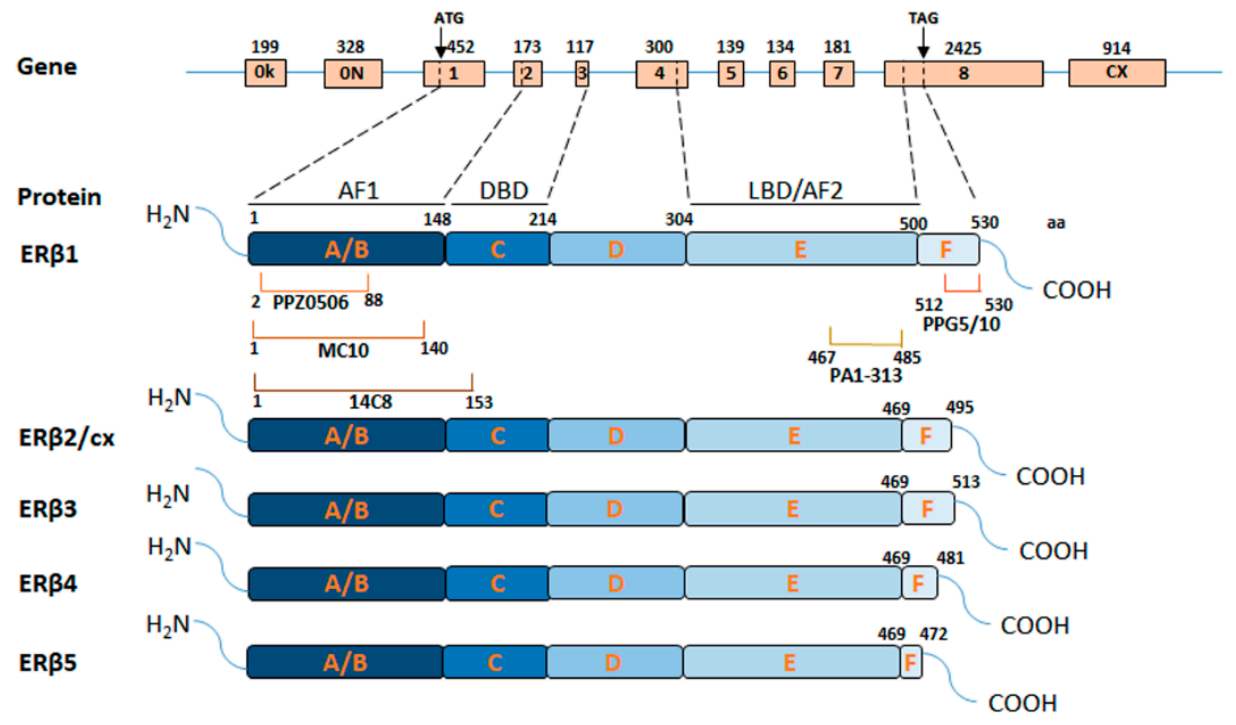

Figure 1. Schematic representation of ER $\beta$ gene, protein isoforms (ER $\beta 1-5)$, and most used antibody epitopes. For the gene, $0 \mathrm{~K}$ and $0 \mathrm{~N}$ represent two promoters at the $5^{\prime}$ end of the gene, exons $1-8$ are represented by boxes, and the introns are represented by lines. CX represents a $3^{\prime}$ non-coding exon present in the long form of ER $\beta 2$ protein $(E R \beta c x)$. Size $(b p)$ of each exon is showed by numbers above boxes, arrows indicate the start (ATG) and the stop (TAG) codons, and dotted lines link gene regions with the encoded protein domains. For protein isoforms, from N-terminus to C-terminus, A/B: activation function 1 (AF1) domain, C: DNA-binding domain (DBD), D: hinge domain, E: ligand-binding domain (LBD) or activation function 2 (AF2) domain, F: C-terminal domain. Square brackets show regions targeted by antibodies PPZ0506, MC10, 14C8, PPG5/10, and PA1-313. Numbers indicate the amino acids of the protein.

\subsection{Issues Raised by Available ERß Antibodies}

Another explanation of the ambiguous data concerning ER $\beta$ role is the poor specificity of commercially available antibodies [65] and the lack of standardization of IHC protocols and tissue samples preparation [66]. Recently, several studies, dedicated to validation of many commonly used anti-ER $\beta$ antibodies, were published [65-68]. The obtained results are summarized in Table 1. 
Table 1. Details of the main ER $\beta$ antibodies applications and performance.

\begin{tabular}{|c|c|c|c|c|}
\hline Reference & ER $\beta$ Antibodies & Source & Tested Applications & Performance \\
\hline \multirow{6}{*}{ Wu et al. [65] } & pAb AB1410 & Chemicon & IHC in human cell lines, IF & Bad \\
\hline & $\mathrm{mAb}$ GR40 & Calbiochem & IHC in human cell lines, IF & Bad \\
\hline & mAb MC9 & Homemade & WB, IP & Good \\
\hline & mAb MC10 & Homemade & WB, IP, IHC in human cell lines and tissues, IF & Good \\
\hline & $\mathrm{mAb}$ PPG5/10 & Thermo Fisher Scientific & IHC in human cell lines and tissues, IF & Good \\
\hline & pAb sc- 6820 & Santa Cruz Biotechnology & IHC in human cell lines, IF & Bad \\
\hline Shanle et al. [66] & pAb PA1-313 & Thermo Fisher Scientific & WB, IHC in mouse xenograft tissues & Good \\
\hline \multirow{8}{*}{ Nelson et al. [68] } & $\mathrm{mAb} 14 \mathrm{C} 8$ & Abcam & WB, RIME & $\begin{array}{l}\text { Low specificity for } \\
\text { RIME application }\end{array}$ \\
\hline & mAb CWK-F12 & DSHB & WB, RIME, IHC in human cell lines & Good \\
\hline & mAb GeneTex 70182 & GeneTex & WB, RIME & Good \\
\hline & $\mathrm{mAb} \mathrm{MC} 10$ & provided by Wu et al. 2012 & WB, RIME & Good \\
\hline & pAb Millipore 06-629 & Millipore & WB, RIME & Bad for WB application \\
\hline & mAb NCL-ER-BETA & Leica Biosystems & WB, RIME & Bad \\
\hline & mAb PPG5/10 & Thermo Fisher Scientific & WB, RIME & Bad for WB application \\
\hline & pAb Sc8974 & Santa Cruz Biotechnology & WB, RIME & Good \\
\hline \multirow{2}{*}{ Andersson et al. [67] } & $\mathrm{mAb} 14 \mathrm{C} 8$ & GeneTex & WB, IP, IHC in human cell lines and tissues & $\begin{array}{l}\text { Bad for WB, IP and IHC in } \\
\text { human tissues applications }\end{array}$ \\
\hline & mAb PPG5/10 & DAKO & WB, IP, IHC in human cell lines and tissues & Bad \\
\hline $\begin{array}{c}\text { Alexandrova et al. } \\
\text { [32] }\end{array}$ & pAb PA1-313 & Thermo Fisher Scientific & IP & Good \\
\hline
\end{tabular}

pAb, polyclonal antibody, mAb, monoclonal antibody, IHC, immunohistochemistry, IF, immunofluorescence, WB, western blot, IP, immunoprecipitation, RIME, rapid immunoprecipitation mass spectrometry of endogenous proteins. 
Antibody tests, done with different methods, indicate the best performance for three of them. The monoclonal antibody PPZ0506, which targets the N-terminal region and recognizes all 5 ER $\beta$ isoforms (Figure 1), displayed the highest receptor specificity. Its use has been validated by Western blot (WB), IHC, and immunoprecipitation coupled to mass spectrometry (IP-MS) using BC cells expressing the exogenous receptor [67]. The polyclonal PA1-313 antibody, targeting the terminal region of $\mathrm{E}$ domain (Figure 1), showed specific binding to ER $\beta 1$ isoform by WB and IHC in mouse xenograft tissues altogether with the ability to immunoprecipitate the receptor [32,66]. Finally, Nelson et al. reported that the monoclonal antibody MC10, which recognizes N-terminal ER $\beta$ part, is suitable for WB and specifically binds ER $\beta$ peptides in rapid immunoprecipitation mass spectrometry of endogenous proteins (RIME) assay [68]. This antibody has been also validated by Wu et al. who also demonstrated its receptor specificity by immunofluorescence and IHC analyses of BC cells and tissues [65].

The results concerning the frequently used monoclonal antibody $14 \mathrm{C} 8$, instead, are controversial; Andersson et al. [67], showed that it is unable to recognize the receptor in IHC experiments on paraffin-embedded ER $\beta$-expressing cell lines; whereas Nelson et al. demonstrated its specificity in WB and its capability to immunoprecipitate ER $\beta$ in RIME, although with low specificity [68]. Discordant evidence has also been described for another commonly used antibody, the monoclonal PPG5/10, which recognizes only ER $\beta 1$ isoform; a study has reported its reliability in IHC analysis in BC cells and tissues [65], others have shown its incapability to specifically detect the receptor by WB $[67,68]$. The discrepancies in results obtained for PPG5/10 and 14C8 antibodies may be caused, not only by the specificity of the antibodies but also by the differences in experimental conditions used, as it was recently suggested by Gustafsson et al. [21]. Hopefully, the data summarized here will help researchers avoid the use of poorly specific antibodies and lead to a lesser discrepancy of the obtained results, to better understand the role of ER $\beta$ and its variants in cancer progression and, finally, to correctly use $\mathrm{ER} \beta$ as a biomarker.

\subsection{ERß Ligands and Their Role in TNBC}

$E R \beta$, similarly to $E R \alpha$, can modulate gene expression in a ligand-independent manner [69] or upon binding to its natural ligand (17 $\beta$-estradiol), but also interact with several synthetic agonists and antagonists [51]. However, because of the high similarity between the ligand-binding cavities of $\mathrm{ER} \alpha$ and ER $\beta$ [70], the identification of selective ligands for ER $\beta$ is still challenging, especially for the treatment of $\mathrm{ER} \alpha$-positive $\mathrm{BC}$.

To date, the prevalent treatment strategies of hormone-sensitive tumors are based on the use of $E R \alpha$-targeting drugs. Based on the mechanisms of action exerted, the ER ligands can be grouped into two main categories [71]: the ones that compete with estrogen and selectively modulate ERs activity (SERMs) and the ones that destabilize the ER via binding to it, inducing its degradation (SERDs). The SERMs, depending on the context where they act, can work as either agonists or antagonists. For example, tamoxifen, the most commonly used SERM in the treatment of ER $\alpha$-positive $\mathrm{BC}$, is known to have an anti-proliferative (or antagonistic) effect on breast tissue [72]. ER $\beta$ has been shown to bind tamoxifen [73], but the results of its action in ER $\alpha$-negative BC are conflicting. Indeed, Esslimani-Sahla et al. associated low levels of ER $\beta$ with tamoxifen resistance [74] while, Hopp and colleagues demonstrated that ER $\beta$ expression had a beneficial effect on the overall survival (OS) in tamoxifen-treated tumors [75]. Finally, Barkhem and colleagues clarified that tamoxifen has an agonist/antagonist function for ER $\alpha$ but a pure antagonist effect for ER $\beta$ [76].

As regards SERDs, ICI 164,384 and ICI 182,780, also known as fulvestrant, are the most diffuse non-selective anti-estrogens [77], proposed as an alternative to endocrine therapy to overcome tamoxifen resistance. However, despite the well-established fulvestrant action on ER $\alpha$, its role on ER $\beta$ remains controversial [78]. In TNBC, fulvestrant synergizing with tamoxifen exerts a therapeutic effect by up-regulation of ER $\beta$ [79]. 
Recently, most of the efforts have been focused on the identification of new selective ER $\beta$ agonists and many synthetic and natural molecules proved to be highly effective for $\mathrm{BC}$ prevention and treatment [80].

One of the first synthetic ER $\beta$ selective ligands reported to have a high affinity for $E R \beta$ is the 2,3-bis(4-hydroyphenyl)-propionitrile, better known as DPN. Different studies reported the use of DPN as ER $\beta$ agonist in TNBC, however, the final effects of its application are discordant; Austin et al. reported that DPN is able to activate ER $\beta$ and increase TNBC cell migration [33]; on the contrary, Song and colleagues demonstrated that ER $\beta$ activation by DPN has an inhibitory effect on migration in different BC cell lines [81]. Interestingly, ER $\beta$-selective antagonist, ERB-041, is able to reduce proliferation in two TNBC cell lines [82].

More recently, several synthetic ligands such as LY700307, WAY200070, and 8 $\beta$-VE2 have shown a high selectivity for ER $\beta$ in different experimental models and promising effects on proliferation, inhibition, and invasiveness suppression in BC, including TNBC [82-86], and are currently being investigated for their therapeutic use.

Among the ER $\beta$ agonists, the phytoestrogens provide a unique therapeutic opportunity to target ER $\beta$ [87]. Two of them, Liquiritigenin [88] and Genistein [89], are able to form stable complexes with ER $\beta$, to recruit selective co-activators and interact with chromatin regulatory elements present in estrogen-responsive genes [87]. It has been reported that both these ligands act as protective factors against BC. In particular, they are able to reduce TNBC invasiveness and growth through the modulation of signaling pathways [82,90-92].

Finally, S-Equol, a soy isoflavone metabolite, displayed a higher ER $\beta$ selectivity when compared to the other plant-derived ligands [93]. Interestingly, it has been approved for clinical trials that started in April 2015 and aimed to determine if S-Equol is effective in decreasing the proliferation rate of TNBC (ClinicalTrials.gov Identifier: NCT02352025).

Interestingly, it has been also reported that ER $\beta$ can inhibit the pro-proliferative role of ER $\alpha$ also via heterodimerization with this ER subtype. Coriano et al. [94] using a multistep screening strategy (cell-based assays and in silico modeling), identified a group of heterodimer-inducing ligands that could represent a valid alternative for hormone-dependent BC targeting.

\subsection{ERß Prognostic Significance in TNBC}

Generally, the expression levels of $E R \beta$ decrease during breast carcinogenesis [6,11,15]; from the highest expression in normal tissues [5], to the complete absence in advanced tumors $[13,16]$. In BC, several reports have defined ER $\beta$ mRNA as a good prognostic marker [95], whereas, others have associated ER $\beta$ presence to endocrine resistance and poor prognosis $[6,96]$. However, it is known that there are many problems linked with mRNA measurements in tumors since, frequently, the mRNA level does not fully predict the protein level. Evaluation of ER $\beta$ expression, based on immunostaining using validated antibodies, has confirmed the applicability of ER $\beta$ as a marker for good prognosis and prolonged disease-free survival, especially in response to tamoxifen therapy $[75,97]$. Data collected in $\mathrm{ER} \alpha$ negative $\mathrm{BC}$ have also provided confounding results: some studies have shown a positive effect of ER $\beta 1$ presence, describing a reduced BC growth and invasiveness [23], and associating its high expression to good tamoxifen responsiveness [54] and to increased disease-free survival (DFS) or OS [98]; other studies indicate the negative effects of ER $\beta 1[30,99]$; furthermore, there are studies claiming that ER $\beta 1$ presence has no prognostic significance (noteworthy, some of these results have been obtained with non-validated antibodies) $[64,100,101]$. Patients with ER $\alpha$ - and PR-negative BCs, but expressing ER $\beta 1$, instead showed a better prognosis regardless of whether the tumor is positive or not to HER2 [24].

Regarding TNBCs, Honma et al. have evaluated the clinical importance of ER $\beta$ in a cohort of 50 patients with TNBCs by IHC and associated ER $\beta 1$ positivity with significantly higher DFS and OS rate at 5 and 10 years [24]. Moreover, Wang et al. investigated ER $\beta 1$ in larger retrospective series of 571 patients with invasive TNBC, detecting the protein in $\sim 30 \%$ of tumor samples, and demonstrated that 
ER $\beta 1$ presence predicts a better OS, DFS, as well as the risk factors for distant metastasis-free survival (DMFS) [102]. They also demonstrated that ER $\beta 1$ can potentially interact with the PTEN/PI3K/pAKT pathway and that ER $\beta 1(+) / \mathrm{pAKT}(-)$ status can predict the most favorable prognosis for TNBC. An opposite behavior, instead, has been described for ER $\beta 5$ isoform, whose expression in TNBC has been associated with a worse outcome [64].

\section{ER $\beta$ Mediated Signaling Pathways in TNBC}

\subsection{ER $\beta$ Effect on Proliferation and Cell Cycle Progression of TNBC}

Uncontrolled cell proliferation is a crucial step in carcinogenesis. Genetic mutations and/or epigenetic modifications can lead to abnormal activation of signaling pathways that promote cell growth and inhibit apoptosis, resulting in cell cycle deregulation [103].

In ER $\alpha$ positive $B C s$, previous studies have suggested that $E R \beta$ could exert its oncosuppressive role targeting cell division. Indeed, in breast cell lines and tumors, its expression has been inversely correlated with that of genes promoting cell cycle [104,105], whereas its exogenous expression induces inhibition of cell proliferation and tumor growth in both cell and mouse xenograft models [106].

Interestingly, anti-proliferative effects of ER $\beta$ have also been reported in ER $\alpha$ negative BCs, including TNBC. In the TNBC cell line MDA-MB-468, Shanle et al. reported that ER $\beta 1$ exogenous expression inhibits cell growth, arresting cell cycle at G1 phase, blocks cell colony formation and reduces tumor size in mice xenografts [107]. Furthermore, treatments with $17 \beta$-estradiol (E2) or ERB-041 enhance these effects, showing an ER $\beta$ ligand-dependent activity too. This effect is due to $E R \beta$ action on target genes, which include the ones involved in Wnt/ $\beta$-catenin pathway (DKK1, WNT4, and CDH1) and in G1/S cell cycle checkpoint control (CDKN1A), two signaling pathways well-known for their role in cancer cell proliferation $[108,109]$.

The ligand-mediated anti-proliferative effects of ER $\beta 1$ have been also demonstrated by Reese et al. in other two TNBC cell lines, MDA-MB-231 and Hs578T [110], where ectopic ER $\beta 1$ inhibits cell proliferation rate after treatments with E2 or ER $\beta$-specific agonists, such as DPN, WAY200070, FERb 033, and Liquiritigenin. On the contrary, treatments with anti-estrogens ICI 182780, (Z)-4-hydroxy-tamoxifen $(4 \mathrm{HT})$, and Endoxifen restored cell growth in both cell lines. In a following study, Reese et al. demonstrated, in MDA-MB-231 cells, that ligand-mediated activation of ER $\beta$ with E2 or LY500307 impacts cell proliferation without inducing apoptosis. Cell cycle analysis, instead, revealed a G1 phase arrest, resulting from the ER $\beta$-mediated downregulation of genes involved in cell cycle progression, including some cyclin-dependent kinases (CDK), such as CDK1 and CDK7, and the cyclins B and H [111].

Recently, Alexandrova et al. [32] have also confirmed these results in three TNBC cell lines (HCC1806, MDA-MB-468, and Hs578T), showing that exogenous expression of ER $\beta 1$ reduces cell proliferation rate increasing G1 cell cycle phase, and inhibits cell clonogenic potential of TNBC cells.

A work from 2011 [112], has also reported that induction of ER $\beta$ expression in MDA-MB-231, is able to abrogate the S-phase, and the Chk1/Cdc25C-mediated G2/M checkpoints in response to DNA damage induced by chemotherapy. ER $\beta$ seems to regulate this signaling, after the treatment with cisplatin and doxorubicin, in p53-defective BC cells but not in wild-type p53-expressing mammary cells, resulting in mitotic catastrophe and decreased cancer cell survival. These promising results suggest that ER $\beta$ presence, in cancers with defective p53, may have a predictive value for a positive response to chemotherapy.

Taken together, these evidences suggest that ER $\beta$ exerts an oncosuppressive role in TNBC by targeting cell cycle genes and slowing down the cell proliferation rate.

\subsection{ER $\beta$ Effect on Invasiveness of TNBC}

TNBCs are notoriously aggressive and prone to metastasize $[44,46]$, but there are evidences that patients with ER $\beta$ positive tumors have shown better OS, DFS, and DMFS [24,102]. These anticancer 
effects seem to be related to the inhibition of canonical signaling pathways leading to blockade of metastatic phenotypes.

Different preclinical studies have demonstrated that ER $\beta$ selective targeting with agonists could be an alternative therapeutic strategy to treat TNBC [113]. For example, as reported by Zhao and colleagues, the use of LY500307 in two different mouse models is able to activate a strong antitumor innate immune response mediated by neutrophils inside metastatic niches. The study revealed that the pharmacological activation of ER $\beta$ induces IL- $1 \beta$ release in tumor cells and enhances innate immunity via recruitment of antitumor neutrophils, resulting in the suppression of metastasis [85].

Reese and colleagues, using ChIP-Seq experiments and microarray analysis, identified a gene group that is differentially regulated by ER $\beta$ after E2 or LY500307 treatment. The authors demonstrated that, in TNBC, the ligand-induced activation of ER $\beta$ generates a potent anticancer effect by the inhibition of TGF- $\beta /$ SMAD pathway, which normally promotes the processes of invasiveness, cell migration, and metastasis formation (Figure 2).

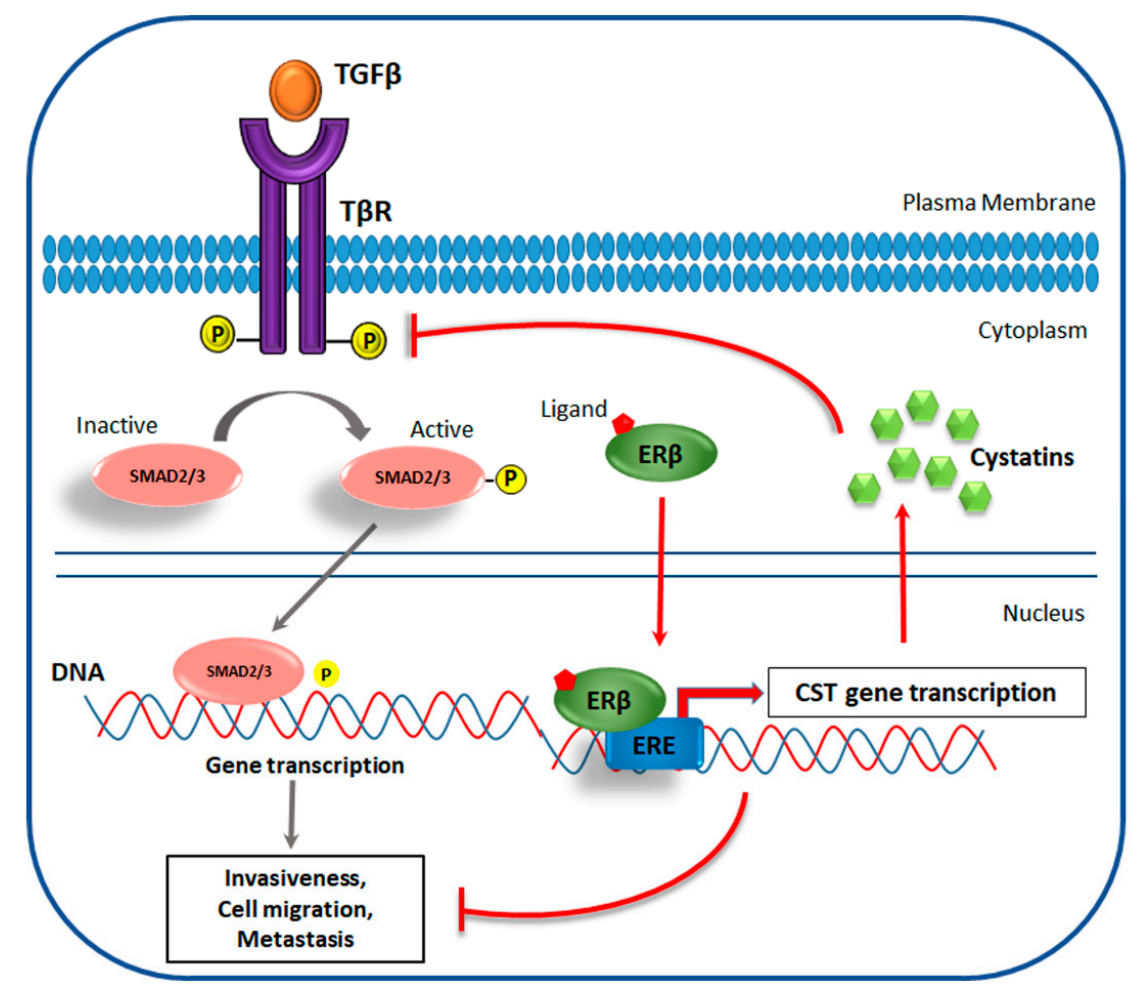

Figure 2. Proposed mechanism of ER $\beta$-mediated inhibition of metastatic phenotype via suppression of TGF- $\beta$ signaling in TNBC. In cancer cells, TGF- $\beta /$ SMAD pathway drives invasiveness, cell migration, and metastasis formation. Ligand-activated ER $\beta$ blocks these processes by binding EREs in the CST genes, enhancing cystatin gene expression; cystatins, in turn, block canonical TGF $\beta$ signaling directly interacting with the TGF $\beta$ receptor (T $\beta R$ ), reducing SMAD2 and SMAD3 phosphorylation.

Indeed $E R \beta$, through the recognition of specific ERE induces the synthesis of a secreted protein family, known as cystatins, that directly blocks TGF $\beta$ signaling and suppresses metastatic phenotypes, both in vitro and in vivo [83].

Additional molecular signaling pathways seem to be involved in the invasiveness of TNBC and the development of metastasis. It has been demonstrated that almost $80 \%$ of TNBC harbor mutations in p53 gene, a well-known oncosuppressor that regulates cell cycle and, hence, inhibits tumor proliferation. The majority of these mutations generally affect the DNA-binding domain of p53 proteins that, as a consequence, lose the tumor suppressor activity and acquire a new oncogenic function. Starting from this observation, Bado et al. demonstrated that the inhibition of p53 mutant proteins is one of the 
mechanisms employed by ER $\beta$ to block epithelial to mesenchymal transition (EMT) and to reduce cell-invasion in TNBC [114].

Moreover, a recent work reported that ER $\beta$ could inhibit EMT also by destabilizing the epidermal growth factor receptor (EGF-R), an oncogene expressed in basal-like cancers. These findings indicate that ER $\beta$ increases the expression of E-cadherins, a group of adhesion molecules that prevent cancer cell migration, via up-regulation of miR-200a/200b/429 and the consequent repression of ZEB1 and SIP1 (Figure 3), two transcription factors that generally inhibit E-cadherin synthesis [115]. Finally, a functional relationship between ER $\beta$ and the androgen receptor (AR) has also been observed. Indeed, Song et al. demonstrated that the activation of AR increases the anti-metastatic effect of ER $\beta$ by functioning as a transcription factor that directly binds to ER $\beta$ promoter [116].

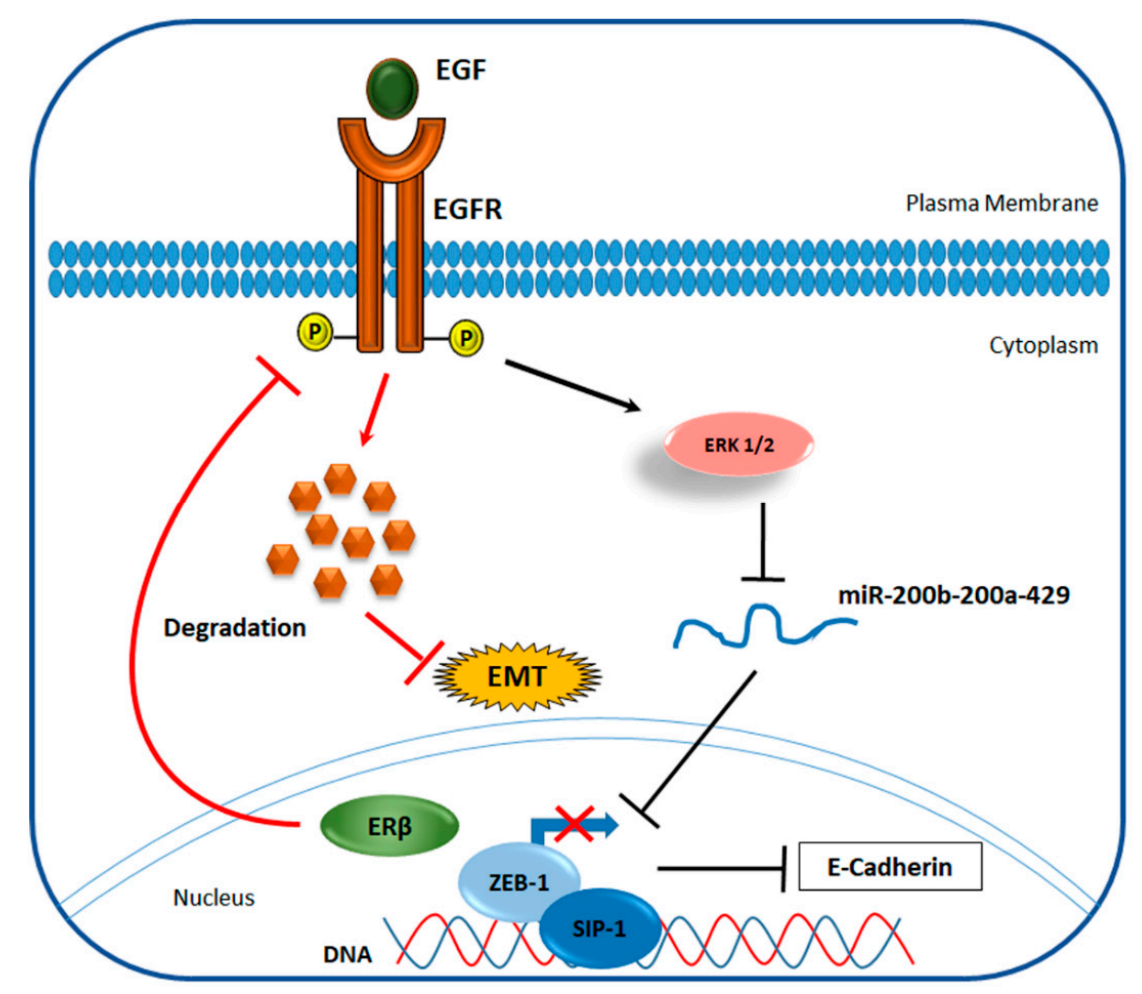

Figure 3. Proposed mechanism of ER $\beta$-mediated inhibition of EMT via EGFR degradation in TNBC. EGF (epidermal growth factor), through the interaction with its receptor (EGFR), promotes epithelial to mesenchymal transition (EMT) in BC cells. Generally, EGFR signaling leads to the phosphorylation and activation of down-stream factors, such as ERK1/2 that, in turn, down-regulates the miR-200b-200a-429. This miRNA family is known to target and inhibit the action of ZEB-1 and SIP-1- transcription factors that repress E-cadherin expression. E-cadherins regulate cellular adhesion and are generally lost in EMT. ER $\beta$ blocks this network through induction of EGFR degradation, leading to up-regulation of E-cadherin protein expression and consequent EMT repression.

Altogether, these findings suggest new promising strategies to reduce the risk of metastasis in TNBC treatment, which involve the targeting of ER $\beta$. Interestingly, starting from May 2019, the use of E2 in treating TNBC patients ER $\beta$ positive has been approved for clinical trials (ClinicalTrials.gov Identifier: NCT03941730).

\subsection{ERß Effect on the Unfolded Protein Response in TNBC}

Accumulation of unfolded proteins in endoplasmic reticulum (EnR), a cellular condition known as EnR stress, is observed in many cancers in response to the limited capability of tumor microenvironment to satisfy the growing request for nutrients and oxygen by cancer cells [117]. To restore protein-folding 
homeostasis, tumor cells activate an adaptive mechanism called unfolded protein response (UPR) [118], which provides cancer cells with alternative survival possibilities or induces cell death by apoptosis in case of severe cell damage [119]. Correlation between EnR stress signaling and cancer development was first suggested in 2004 [120] and has since been widely accepted by the scientific community [121]. In BC cells, it was demonstrated that UPR signaling promotes a malignant phenotype and can confer therapeutic resistance [122,123]. Indeed, its activation has been associated with reduced sensitivity to antiestrogens $[124,125]$ and chemotherapy resistance [126,127].

One of UPR signaling branches is regulated by inositol-requiring enzyme $1 \alpha$ (IRE1 $\alpha)$, an EnR transmembrane protein that contains functional kinase and RNase domains. In normal conditions, IRE1 $\alpha$ is bound to binding immunoglobulin protein (BIP) that prevents its dimerization and dissociates in response to EnR stress (Figure 4) [128]. When released from BIP, IRE1 $\alpha$ self-dimerizes and undergoes autophosphorylation leading to a conformational change that activates the RNase domain. Activated IRE1 $\alpha$ then splices a 26-nucleotide intron from the mRNA encoding for X-box-binding protein 1 (XBP1), causing an open reading frame shift and expression of an activated XBP1 form-spliced XBP1 (XBP1s) $[129,130]$. XBP1s functions as a transcription factor and induces the expression of genes involved in protein folding, EnR-associated protein degradation and protein secretion, whose activation abolishes the accumulated unfolded protein [131,132].

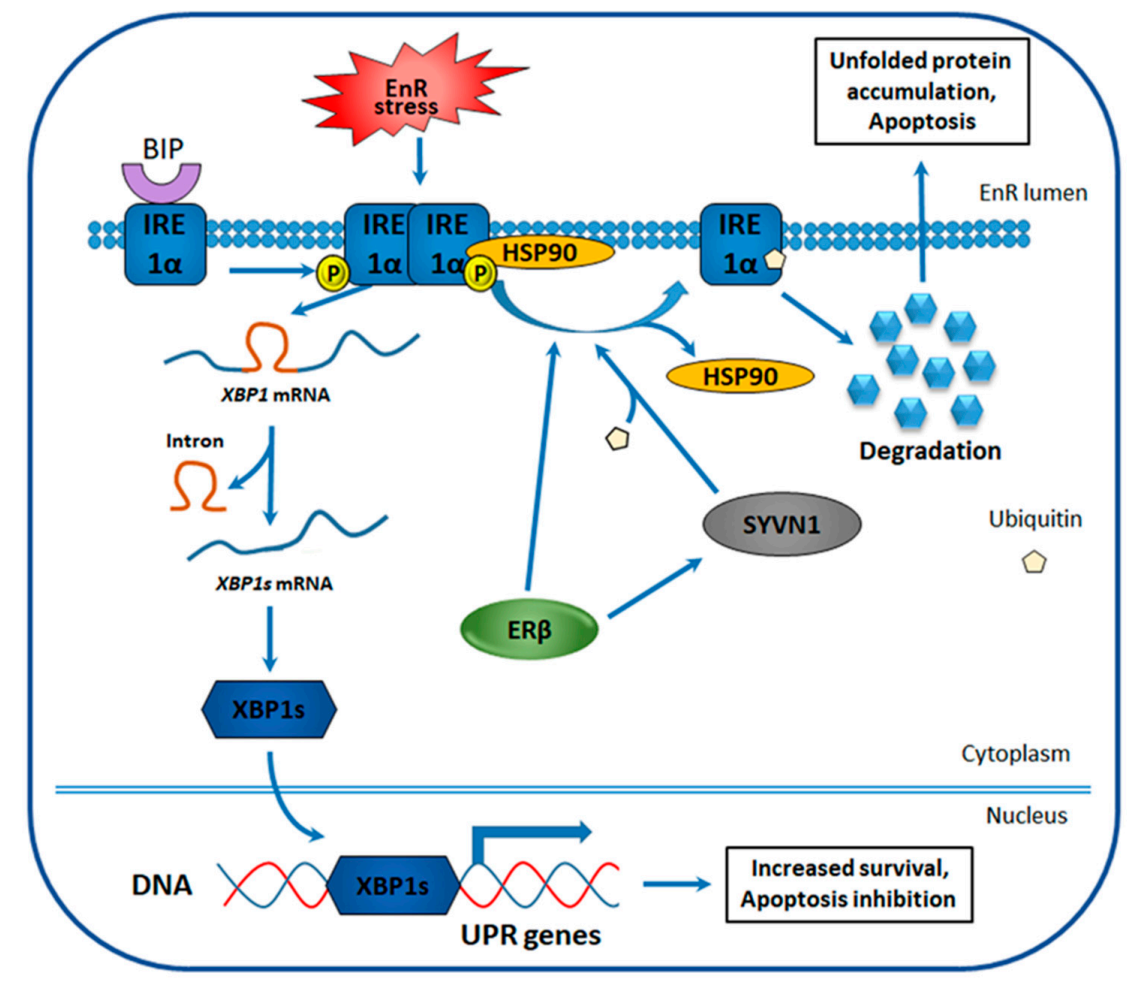

Figure 4. Proposed mechanism of ER $\beta$-mediated regulation of unfolded protein response (UPR) in TNBC. Endoplasmic reticulum (EnR) stress activates inositol-requiring enzyme $1 \alpha$ (IRE1 $\alpha)$, IRE1 $\alpha$ self-dimerizes and undergoes autophosphorylation, then IRE1 $\alpha$ induces X-box-binding protein 1 (XBP1) mRNA splicing with the formation of spliced XBP1 (XBP1s) mRNA. XBP1s-encoded protein functions as a potent transcription factor that triggers UPR-involved gene expression, whose expression promotes cell survival and inhibits apoptosis. ER $\beta$ induces dissociation of heat shock protein 90 (HSP90) from IRE1 $\alpha$ and increases the expression of Synoviolin 1 (SYVN1) that ubiquitinates IRE1 $\alpha$. Both processes are known to induce IRE1 $\alpha$ degradation, leading to downregulation of pro-survival XBP1s, unfolded protein accumulation in EnR, and apoptosis.

There are several evidences indicating that IRE1 $\alpha$-XBP1 UPR signaling branch plays a role in TNBC tumorigenicity, one of which is the correlation between high XBP1s expression level and poor 
prognosis observed in TNBC patients [133]. Another study showed that XBP1 depletion in TNBC cell line models inhibits tumor growth, decreases tumor relapse and the $\mathrm{CD} 44^{\text {high }} \mathrm{CD} 24^{\text {low }}$ population of cancer stem cells [134], known to mediate cancer recurrence [135-137]. Analysis of XBP1 chromatin binding demonstrated that XBP1 cooperates with another transcription factor hyper-activated in TNBC, the hypoxia-inducing factor $1 \alpha(\mathrm{HIF} 1 \alpha)[138,139]$, which recruits RNA polymerase II transcriptional machinery and drives the expression of HIF1 $\alpha$ target genes [134].

ER $\beta$ involvement in the TNBC cell sensibilization to EnR stress-stimulating therapy was suggested basing on the enhanced apoptosis observed in ER $\beta 1$-expressing TNBC cells treated with these drugs [140]. Investigation of underlying mechanisms revealed that although unspliced XBP1 expression is not influenced by ER $\beta, \mathrm{XBP} 1 \mathrm{~s}$ amount is significantly reduced in the presence of the receptor in EnR stress conditions [140]. Corroborating this observation, the mRNA level of XBP1s target genes, known to participate in UPR, was also decreased. The same experiments were also performed for another ER $\beta$ isoform-ER $\beta 2$, whose upregulation failed to induce apoptosis and inhibit XBP1s expression in response to EnR stress, indicating the specificity of the observed effects for full-length ER $\beta$. Further research revealed that the inhibition of XBP1s expression is a result of reduced IRE1 $\alpha$ protein expression in ER $\beta$-positive cells [140]. At the same time, IRE1 $\alpha$ mRNA expression, in the absence of EnR-induced stress, was not affected, indicating an ER $\beta$-mediated post-transcriptional regulation of IRE1 $\alpha$ expression, known to occur through increased ubiquitination and degradation. Two proteins are known to regulate IRE1 $\alpha$ degradation: E3 ubiquitin ligase, Synoviolin (SYVN1), and the molecular chaperone heat shock protein 90 (HSP90). SYVN1 ubiquitinates IRE1 $\alpha$, whereas HSP90 binds IRE1 $\alpha$ to protect it from degradation and renders IRE1 $\alpha$ accessible to proteases upon dissociation from it $[141,142]$. Evaluation of their possible role in TNBC revealed that ER $\beta$-expressing cells overexpress SYVN1 and are characterized by a decreased association of IRE1 $\alpha$ with HSP90 (Figure 4) [140]. These results indicate that ER $\beta$ presence sensitizes TNBC cells to EnR stress-inducing drugs through repression of IRE1 $\alpha$-XBP1 signaling branch of UPR.

\subsection{ER $\beta$ Effect on the Bioenergetics of TNBC}

Energy metabolism represents a fundamental molecular process in cancer cells and a better understanding of mechanisms, underlying its regulation, can provide new therapeutic strategies to selectively eliminate cancer cells by targeting their unique metabolism.

Adenosine triphosphate (ATP) production in normal cells relies primarily on a process called oxidative phosphorylation (OXPHOS), that occurs in the mitochondria and is regulated by mitochondrial DNA (mtDNA)-encoded genes [143]. This way of ATP production is highly efficient and is preferred by most body cells. Cancer cells, instead, even in aerobic conditions favor ATP production by glycolysis, a phenomenon known as the Warburg effect in oncology [144]. Aerobic glycolysis occurs in the cytoplasm and is characterized by enhanced enzymatic activity and increased glucose uptake by cancer cells. Among the main factors causing this metabolic shift there are aberrant oncogene activity, loss of tumor suppressor expression, hypoxic microenvironment, mutations in mtDNA, and impairment of mitochondrial function [145-147].

Analysis of metabolic phenotype of TNBC tissues revealed that, similarly to genomic heterogeneity, TNBCs are characterized by high metabolic heterogeneity $[148,149]$. There is some evidence indicating the correlation between the metabolic characteristics of TNBCs and therapeutic responsiveness. For example, it was shown that exposure of TNBC cells to high glucose concentrations induces proliferation and abrogates the apoptotic effects induced by the drug metformin [150]. Other studies demonstrated that combined treatments, inducing the metabolic switch from glycolysis to OXPHOS, increases the sensitivity of TNBC cells to mitochondrial respiratory complex I inhibitors [151]; whereas inhibition of aerobic glycolysis enhances antitumor efficacy of Zoptarelin Doxorubicin, a cytotoxic agonist of gonadotropin-releasing hormone receptor (GnRH-R), expressed in more than $70 \%$ of TNBC tumors [152]. Altogether, these studies indicate that combinational treatment, including energy metabolism-targeting agents, may represent a therapeutic strategy for aggressive TNBC treatment. 
ER $\beta$ localization in mitochondria has been described for the first time by Yang et al. [153] in 2004, who observed the presence of ER $\beta$-mapping peptides in human heart mitochondria lysate by mass spectrometry (MS) [153]. This result suggested that estrogens could directly affect the functions of this important organelle through ER $\beta$, hypothesis further confirmed by numerous studies. Indeed, $E R \beta$ was detected in mitochondria of rat (uterus, ovarian, hippocampus, and neuronal cells) and human (cardiomyocytes, sperm, periodontal ligament, and cultured lens epithelial cells) tissues, altogether with BC (MCF7), hepatocarcinoma (HepG2), and osteosarcoma (SaOS-2) cell lines [154]. It was suggested that transportation of $E R \beta$ into the mitochondria occurs through the targeting of TOM20 and/or TOM70 import receptors, both belonging to the translocase of the outer membrane of mitochondria (TOM) complex (Figure 5), but through different mechanisms [155]. For example, TOM 20 functions as preprotein receptor and preferentially binds to presequences $\phi X X \phi \phi$ (where $\phi$ and $X$ are hydrophobic and any amino acids respectively), it imports ER $\beta$ into the mitochondria through interaction with one of the four ER $\beta$ presequence motifs. TOM 70, instead, may transport ER $\beta$ with the aid of molecular chaperone complex, formed by HSP70 and HSP90 heat shock proteins, by docking through tetraticopeptide repeat motifs (TPR) [155]. Indeed, in MCF7 cells it was demonstrated that $\mathrm{ER} \beta$ translocation to mitochondria is dependent on receptor interaction with glucose-regulated protein 75 (GRP75), a chaperone protein belonging to Hsp70 family [156].

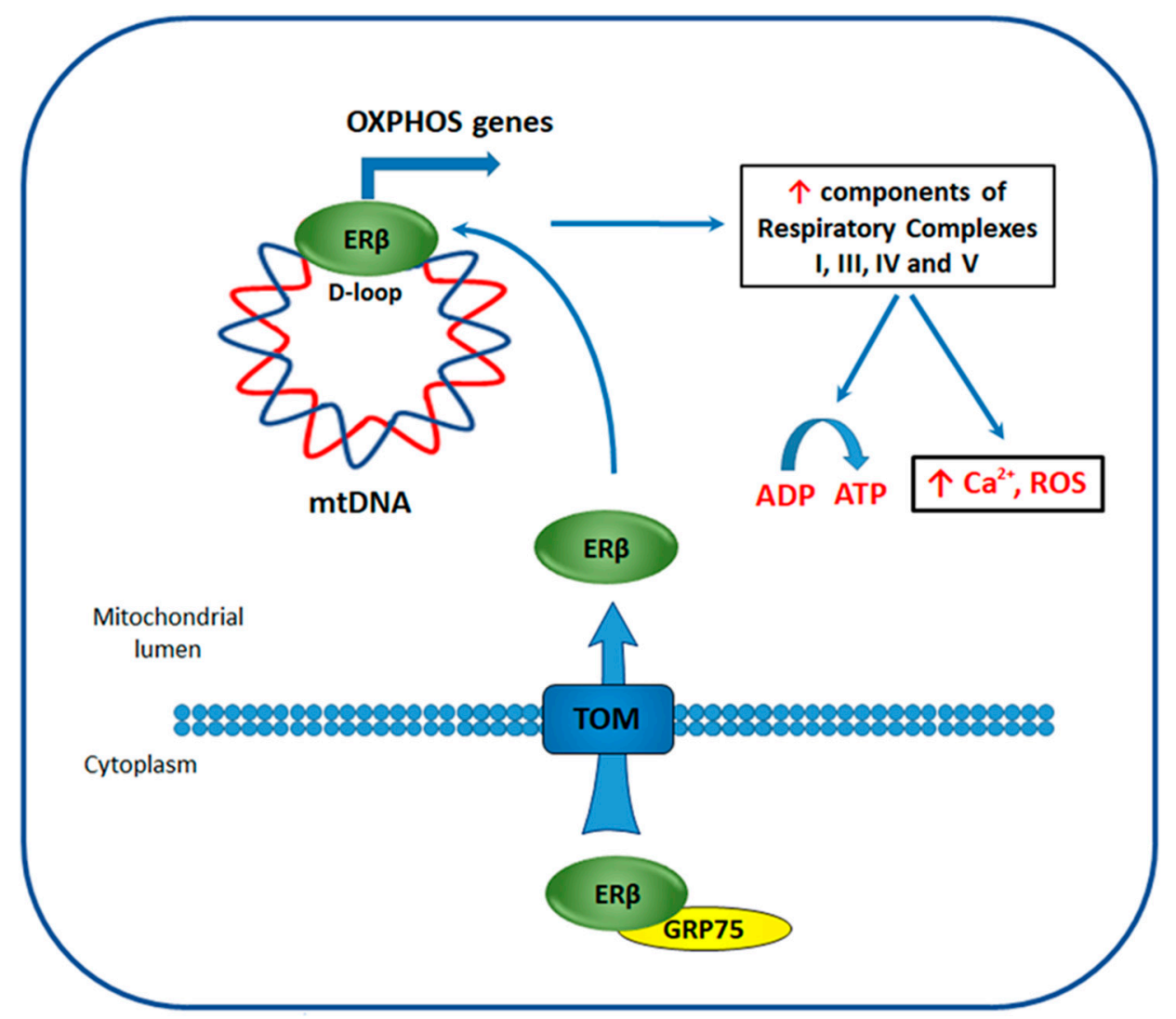

Figure 5. Proposed mechanism of ER $\beta$-mediated regulation of oxidative phosphorylation (OXPHOS) in TNBC. ER $\beta$ interacts with glucose-regulated protein 75 (GRP75) and undergoes translocation into the mitochondria with the aid of the translocase of the outer membrane (TOM) complex. In mitochondria, ER $\beta$ binds to mitochondrial DNA (mtDNA) in displacement loop (D-loop) region and drives the expression of genes encoding for the components of respiratory complexes I, III, IV, and V, responsible for OXPHOS. OXPHOS activation leads to an increase of mitochondrial $\mathrm{Ca}^{2+}$, reactive oxygen species (ROS), and ATP concentrations. 
Mechanisms of mitochondrial ER $\beta$ action has been extensively studied in hormone-responsive $\mathrm{BC}$, where it was demonstrated that treatment with E2 enhances ER $\beta$ mitochondrial localization in a concentration- and time-dependent manner [157]. Moreover, it was shown that ER $\beta$, through the binding to EREs present in the mtDNA displacement loop (D-loop) (Figure 5) [158], regulates the expression of mtDNA genes encoding for proteins of the mitochondrial respiratory chain, such as cytochrome c oxidase subunit (CO) I, CO II, CO III, ATP synthase subunits 6 and 8 , and the mitochondrial transcript precursor [159].

Moreover, the specific evaluation of ER $\beta$ mitochondrial role in TNBC cells has demonstrated that its mitochondria-targeted (mitoER $\beta$ ) expression is able to inhibit proliferation, cell cycle progression, and reduce colony and spheroid formation [156]. These effects were abrogated upon deletion of C- or $\mathrm{N}$-terminal fragments of mitoER $\beta$ protein in cell culture and mice xenograft models [156]. Further analysis revealed that full-length mitoER $\beta$ expression induces transcription of 13 mitochondrial genes through binding to mtDNA D-loop, an effect that was not observed in case of the introduction of C- or N-terminally-truncated receptor variants. Among 13 genes, whose expression was affected, components of respiratory complexes I, III, IV, and V were present, including mtDNA-encoded genes regulated by ER $\beta$ in hormone-responsive BC. Finally, increased levels of mitochondrial $\mathrm{Ca}^{2+}$, reactive oxygen, and ATP production were observed in the presence of mitoER $\beta$ [156]. In our previous study [32], GRP75 was present among putative ER $\beta$ interactors, determined by MS, in TNBC cells indicating its possible role in the receptor translocation to mitochondria also in this BC subtype. All these results indicate that $E R \beta$ activates transcription of mtDNA-encoded genes leading to the activation of OXPHOS in TNBC cells.

\subsection{ER $\beta$ Effect on Cholesterol Biosynthesis}

Cholesterol biosynthesis is another metabolic process, whose reprogramming favors cancer cells adaptation to environmental conditions and sustain an increased proliferation rate $[160,161]$. Cholesterol is critical for cellular homeostasis maintenance and necessary for membrane integrity and fluidity, being a key component of the plasmatic membrane lipid rafts that scaffold extracellular signaling [162]. Moreover, cholesterol represents an essential precursor for the synthesis of steroid hormones (e.g., estrogen and progesterone [163]), vitamins (e.g., vitamin D), and bile acids. Cellular cholesterol comes from two main sources: external environment and intracellular synthesis. Cancer cells are often characterized by high cholesterol level, which is fueled more by increased intracellular synthesis than by serum cholesterol $[161,164,165]$, suggesting that altered cholesterol homeostasis may trigger or at least support tumorigenesis.

Deregulation of cholesterol biosynthesis occurs by multiple processes including cholesterol import, synthesis, export, metabolism, and esterification [161,162]. Sterol regulatory element-binding proteins (SREBPs) are the main regulators of these metabolic processes, and function as transcription factors that bind sterol regulatory elements and drive expression of more than 30 lipid biogenesis genes [166]. Three SREBP proteins, SREBP1a, SREBP1c, and SREBP2, are known. They differ by their preferences in gene expression activation. SREBP1a is a potent driver of expression of all SREBP-responsive genes, including the ones necessary for cholesterol, fatty acids, and triglycerides biosynthesis; whereas SREBP1c and SREBP2 actions are more specific and comprise transcription of fatty acid synthesis for SREBP1c and cholesterol biosynthesis genes for SREBP2 [167]. Cholesterol biosynthesis in cancer is known to be regulated by PI3K/AKT/mTOR, RTK/RAS, and mutated p53 through SREBP activation by mechanisms that have been previously reviewed $[160,161]$.

Analysis of cholesterol metabolic pathway activity in BC revealed that TNBC tumors are characterized by a hyper-activated cholesterol biosynthesis and efflux compared to the majority of ER $\alpha$-positive BC tumors $[168,169]$. Recently, in TNBC cells, it was described that cholesterol metabolism is regulated by RAR-related orphan receptor gamma $(\mathrm{ROR} \gamma)$, which facilitates SREBP2 recruitment to cholesterol biosynthesis genes and whose genetic and pharmaceutical inhibition causes tumor regression, thus representing an excellent target for TNBC treatment [168]. Other important 
regulators of cholesterol metabolism in TNBC are p53 mutants, derived from wild type protein by substitutions of amino acids $\mathrm{R} 280 \mathrm{~K}$ or $\mathrm{R} 273 \mathrm{H}$, located in p53 DNA-binding domain and directly interacting with DNA. These two p53 mutants, partly through the cooperation with SREBP, associates with sterol gene promoters leading to the activation of mevalonate pathway and causing a significant phenotypic effect on breast tissue architecture [164]. Moreover, it was demonstrated that p53 mutations correlate with high expression of genes encoding for components of cholesterol biosynthesis in BC [164] that, considering high p53 mutation rate in TNBC [170], suggests that targeting cholesterol biosynthesis could be a treatment option for patients with TNBC.

Recently, Alexandrova et al. [32] described that ER $\beta$ regulates cholesterol biosynthesis in TNBC through inhibition of all three branches of this metabolic pathway. This observation was based on transcriptomic analyses performed in three TNBC cell lines, belonging to different subtypes and expressing exogenous ER $\beta$, pointing to a subtype-independent effect of this receptor in TNBC. SREBP1 and SREBP2 were among the upstream regulators found responsible for the observed phenotype and genome-wide analysis of ER $\beta$ binding to TNBC cell genome and the nature of its molecular partners revealed that ER $\beta$ inhibits SREBP1 expression by binding to its DNA regulatory elements and recruiting chromatin repressive complexes such as polycomb repressor complexes 1 and 2 (PRC1/2) (Figure 6), that probably suppress SREBP1 expression through the introduction of repressive epigenetic marks [32]. Further investigation of mechanisms of ER $\beta$-mediated regulation of cholesterol biosynthesis revealed that small non-coding RNAs are also involved in the regulation of this metabolic process. In particular, it was demonstrated that miR-181a-5p expression could be regulated by ER $\beta$ by an unknown mechanism (Figure 6). In fact, its upregulation has been described in both TNBC cell lines, after induction of ER $\beta$ expression, and in ER $\beta$-positive vs. -negative biopsies. Moreover, among the predicted targets of miR-181a-5p, key components of cholesterol biosynthesis were present [171]. Altogether, these results indicate the involvement of different epigenetic mechanisms in ER $\beta$-mediated regulation of cholesterol biosynthesis in TNBC.

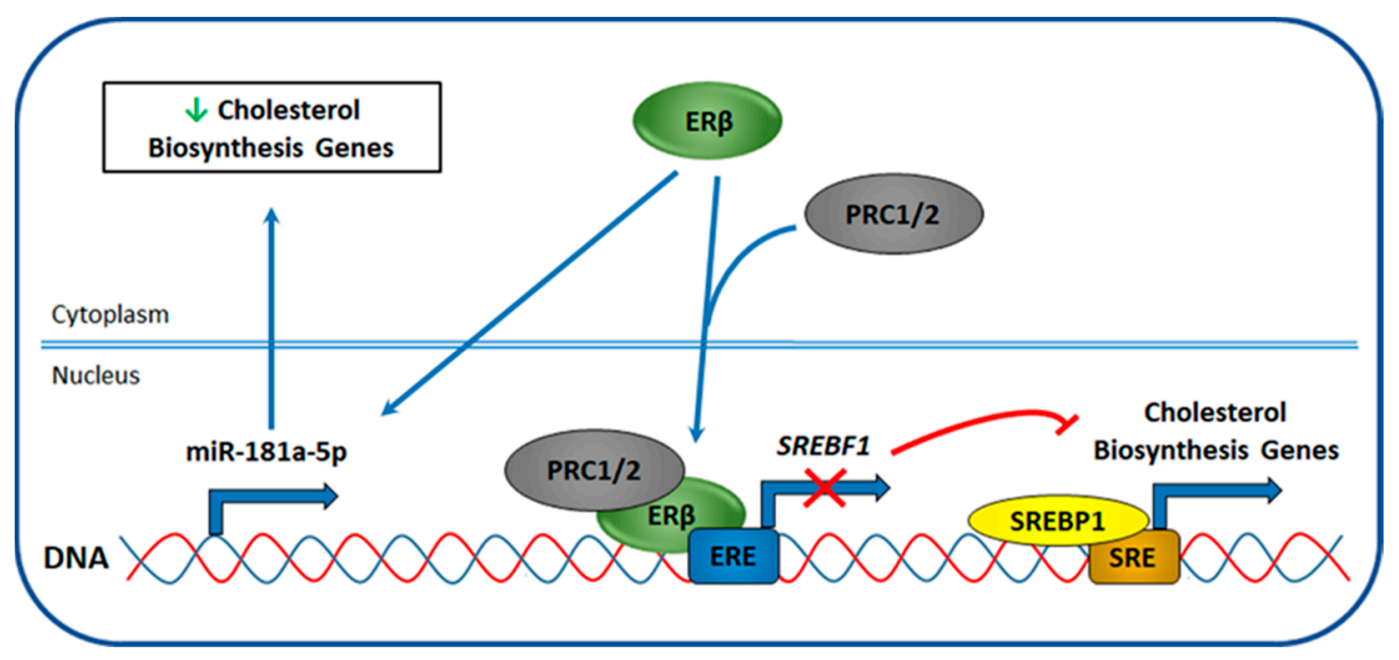

Figure 6. Proposed mechanism of ER $\beta$-mediated regulation of cholesterol biosynthesis in TNBC. ER $\beta$ interacts with chromatin repressive complexes, e.g., polycomb repressive complexes 1 and 2 (PRC1/2), binds to ERE present in sterol regulatory element binding factor 1 (SREBF1) gene promoter and inhibits SREBF1 expression. SREBF1 gene encodes for sterol regulatory element binding protein 1 (SREBP1), which drives expression of cholesterol biosynthesis genes by binding to sterol regulatory elements (SREs) present in their promoters. Inhibition of SREBF1 transcription reduces expression of SREBP1-driven genes leading to the downregulation of cholesterol biosynthesis. Alternatively, ER $\beta$ by unknown mechanism induces expression of miR-181a-5p, which targets cholesterol biosynthesis genes and regulates their expression post-transcriptionally. 


\subsection{ERß Effect on AR Signaling Pathways}

Recent researches have revealed that a group of TNBC expresses the AR, allowing the definition of a luminal androgen receptor (LAR) subtype [172,173]. Moreover, it has been demonstrated that AR plays a pro-proliferative activity in preclinical models, which opened the possibility of using two anti-androgens, bicalutamide and enzalutamide, in TNBC treatment [174-176]. Clinical trials for both drugs in metastatic TNBC have revealed promising results and a higher clinical benefit for enzalutamide [175,176]. Moreover, in 2016 started a phase II clinical trial, aiming to assess the use of enzalutamide in early-stage AR-positive TNBC (NCT02750358). A recent study proposed a connection between ER $\beta$ and AR receptor in TNBC, suggesting that ER $\beta$ oncosuppressive role in AR-positive TNBC is mediated by the direct and indirect interactions with AR [177]. The authors, using MDA-MB 453 cells, demonstrated that the ER $\beta$ presence increases the sensitivity of TNBC cells to anti-androgens, especially to enzalutamide. In fact, enzalutamide treatment enhances the formation of AR:ER $\beta$ heterodimer, preventing AR from forming homodimers. Then the heterodimer enters the nucleus where it is unable to bind androgen-responsive element (ARE) sequences and promote the expression of cell growth genes. These results suggest that a new therapeutic option, consisting of a combined therapy targeting both receptors, may be useful for TNBC patients, whose tumors express both ER $\beta$ and AR receptors.

\section{Conclusions}

TNBC is an extremely aggressive BC subtype that lacks well-defined therapeutic targets and for this reason, has limited treatment options, which is prompting researchers to study the molecular mechanisms that drive TNBC onset and progression. One of the suggested targets for TNBC treatment is $E R \beta$, but to date, its role in cancer progression is still debated because of several reasons, the main of which are poor specificity of available ER $\beta$ - recognizing antibodies and existence of several receptor isoforms [55] that exert an opposite effect on the cancer growth (discussed in Section 3.1). Recently, a strong effort has been made to solve some of these problems and several works were published where the performance of the most frequently used anti-ER $\beta$ antibodies has been validated using different techniques [65-68]. The obtained results are summarized in Section 3.2 and Table 1. Using extensively validated anti-ER $\beta$ antibodies, it has been demonstrated that $15-30 \%$ of TNBCs express the ER $\beta$ receptor [32,102], but the data concerning prognostic value of the receptor expression in TNBC patients are still scarce and additional studies using larger and better-characterized patient cohorts are necessary, especially in relation to different ER $\beta$ isoforms. Nevertheless, there are multiple experimental data demonstrating the anti-proliferative and anti-migratory effects of exogenous ER $\beta 1$ in TNBC cell lines and mice xenograft models $[32,107,110,111]$, indicating the possibility of antitumor ER $\beta 1$ action also in vivo. Importantly, the existence of selective ER $\beta$ agonists $[80,84,85,87]$, summarized in Section 3.3, allows to enhance the tumor suppressor effect guided by the receptor in vitro, and, once the problems with ER $\beta$ detection in human tissues is solved, they could be successfully used to activate ER $\beta$ in TNBC patients, without stimulating the pro-proliferative program driven by ER $\alpha$ in normal human cells.

In this review, we have highlighted the ER $\beta$ involvement in the different molecular pathways composing the complex network of signaling processes, regulating TNBC onset and progression.

The most interesting mechanisms of ER $\beta$ action in TNBC are linked to the regulation of cellular metabolic programs, which takes place through ER $\beta$-mediated downregulation of UPR in the presence of EnR stress [140], induction of OXPHOS by expression of mtDNA-encoded genes [156] and inhibition of cholesterol biosynthesis by suppression of SREBF1 gene transcription [32] or upregulation of miR-181a-5p [171]. ER $\beta$ is also able to drive expression of cystatins, that promote inhibition of TGF $\beta$ signaling leading to the reduced metastatic potential of TNBC cells in vitro and in vivo [83]. Moreover, ER $\beta$ has been associated several times with drug sensitivity. In fact, there is evidence that ER $\beta$ expression sensitizes tumor cells to anti-androgen therapy, in AR-positive TNBC model [177], and to chemotherapy drugs doxorubicin and cisplatin in the presence of defective p53 [112]. 
Altogether, these data indicate that TNBC patients may potentially benefit from administration of ER $\beta$-targeted therapy singularly or in combination with chemotherapeutical drugs [178], anti-androgen therapy $[179,180]$, EnR stress-inducing substances [181,182], or inhibitors of cholesterol biosynthesis $[183,184]$, some of which are already used for the treatment of other diseases. There is no doubt that all these treatment strategies require further extensive validation and testing, and a better understanding of the ER $\beta$-dependent regulatory mechanisms, revised here may be useful toward the identification of new and effective ways to treat ER $\beta$-positive TNBCs.

Author Contributions: Conceptualization, E.A., Y.D., G.P., F.R., A.S., and A.W; writing and original draft preparation, E.A., Y.D., F.R., J.L., and D.M.; writing, review and editing, A.S., Y.D., E.A., J.L., G.P., D.M., D.R., E.C., G.G., G.N., R.T., A.W., and F.R.; funding acquisition, G.G., G.N., F.R., R.T., and A.W. All authors have read and agree to the published version of the manuscript.

Funding: This work was supported by Italian Association for Cancer Research (grant number IG-23068), University of Salerno (Fondi FARB 2017), Regione Campania, Progetto GENOMAeSALUTE (POR Campania FESR 2014/2020, azione 1.5; CUP:B41C17000080007), Regione Campania ("La Campania lotta contro il cancro" project Rare-Plat-Net, CUP: B63D18000380007), and Genomix4Life Srl. E.A. is a Fellow of Fondazione Umberto Veronesi. G.P. and J.L are PhD students of the Research Doctorates in "Biomedical Sciences and Technologies" of the University Roma Tre and "Molecular and Translational Oncology and Innovative Medical-Surgical Technologies" of the University of Catanzaro "Magna Graecia," respectively.

Conflicts of Interest: The authors declare no conflict of interest.

\section{Abbreviations}

\begin{tabular}{|c|c|}
\hline $4 \mathrm{HT}$ & (Z)-4-hydroxy-tamoxifen \\
\hline ATP & Adenosine Triphosphate \\
\hline $\begin{array}{l}\text { AF1/AF2 } \\
\text { domain }\end{array}$ & Activation Function 1/2 domain \\
\hline $\mathrm{AKT}$ & Protein Kinase B \\
\hline AR & Androgen Receptor \\
\hline ARE & Androgen-Responsive Element \\
\hline BC & Breast Cancer \\
\hline BIP & Binding Immunoglobulin Protein \\
\hline Cas & CRISPR-associated protein \\
\hline Csc25C & M-phase inducer phosphatase 3 \\
\hline CD24 & CD24 antigen \\
\hline CD44 & CD44 antigen \\
\hline CDH1 & Cadherin-1 \\
\hline CDK & Cyclin-Dependent Kinase \\
\hline CDKN1A & Cyclin-Dependent Kinase Inhibitor 1A \\
\hline ChIP-Seq & Chromatin Immunoprecipitation Sequencing \\
\hline Chk1 & Checkpoint Kinase 1 \\
\hline $\mathrm{CO}$ & Cytochrome C Oxidase \\
\hline CRISPR & Clustered Regularly Interspaced Short Palindromic Repeat \\
\hline D-loop & mtDNA Displacement loop \\
\hline DBD & DNA-Binding Domain \\
\hline DFS & Disease-Free Survival \\
\hline DKK1 & Dickkopf-related protein 1 \\
\hline DMFS & Distant Metastasis-Free Survival \\
\hline $\mathrm{DPN}$ & 3-bis(4-hydroyphenyl)-propionitrile \\
\hline E2 & $17 \beta$-estradiol \\
\hline EGFR & Epidermal Growth Factor Receptor \\
\hline EMT & Epithelial to Mesenchymal Transition \\
\hline EnR & Endoplasmic Reticulum \\
\hline $\mathrm{ER} \alpha$ & Estrogen Receptor $\alpha$ \\
\hline $\mathrm{ER} \beta$ & Estrogen Receptor $\beta$ \\
\hline ERE & Estrogen Response Element \\
\hline
\end{tabular}




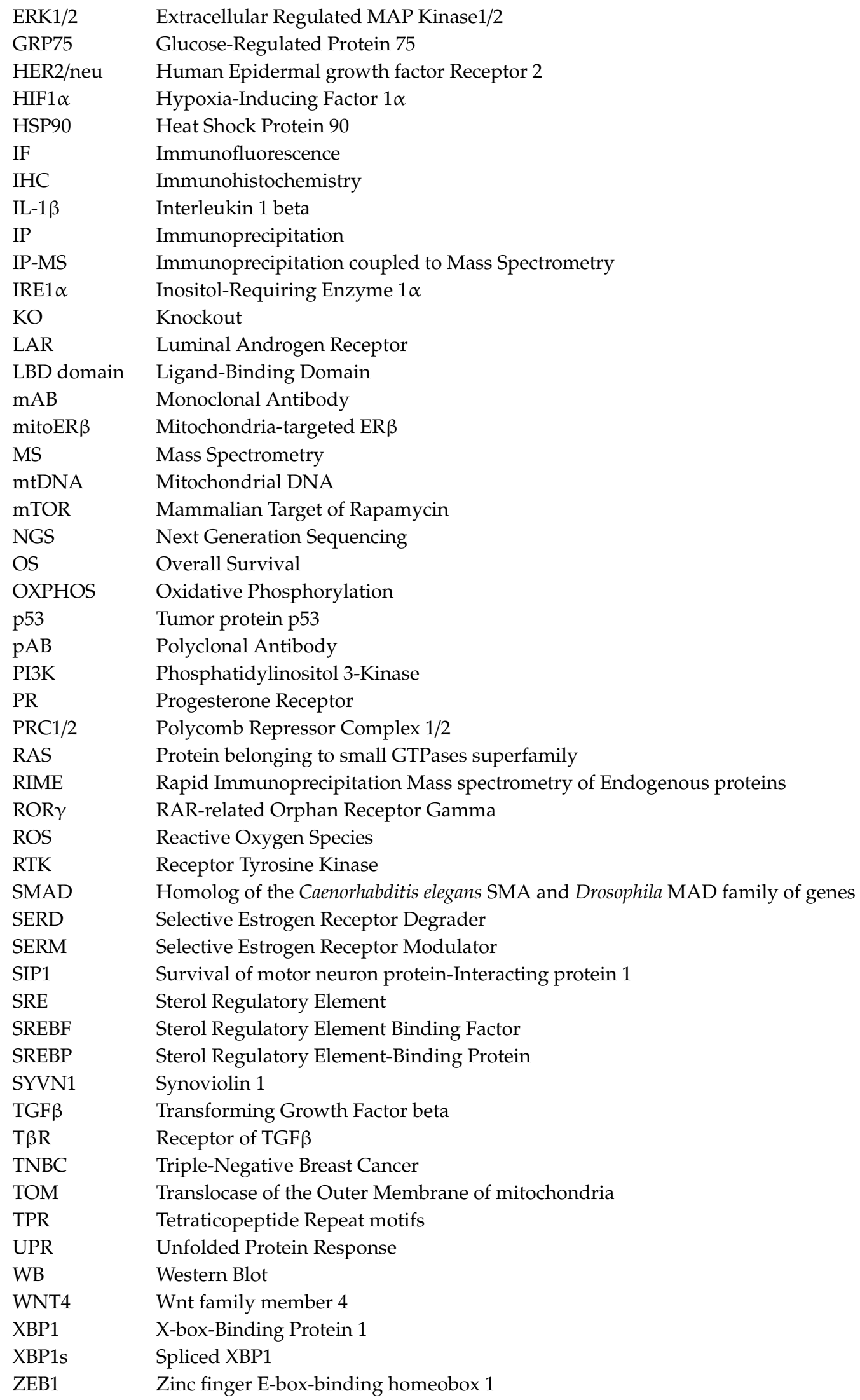




\section{References}

1. Marino, M.; Galluzzo, P.; Ascenzi, P. Estrogen signaling multiple pathways to impact gene transcription. Curr. Genom. 2006, 7, 497-508. [CrossRef]

2. Deroo, B.J.; Korach, K.S. Estrogen receptors and human disease. J. Clin. Investig. 2006, 116, 561-570. [CrossRef]

3. Ali, S.; Coombes, R.C. Estrogen receptor alpha in human breast cancer: Occurrence and significance. J. Mammary Gland Biol. Neoplasia 2000, 5, 271-281. [CrossRef]

4. Kuiper, G.G.; Enmark, E.; Pelto-Huikko, M.; Nilsson, S.; Gustafsson, J.A. Cloning of a novel receptor expressed in rat prostate and ovary. Proc. Natl. Acad. Sci. USA 1996, 93, 5925-5930. [CrossRef]

5. Speirs, V.; Skliris, G.P.; Burdall, S.E.; Carder, P.J. Distinct expression patterns of ER alpha and ER beta in normal human mammary gland. J. Clin. Pathol. 2002, 55, 371-374. [CrossRef] [PubMed]

6. Leygue, E.; Dotzlaw, H.; Watson, P.H.; Murphy, L.C. Altered estrogen receptor $\alpha$ and $\beta$ messenger RNA expression during human breast tumorigenesis. Cancer Res. 1998, 58, 3197-3201. [PubMed]

7. Mehta, R.G.; Hawthorne, M.; Mehta, R.R.; Torres, K.E.; Peng, X.; McCormick, D.L.; Kopelovich, L. Differential roles of ERalpha and ERbeta in normal and neoplastic development in the mouse mammary gland. PLoS ONE 2014, 9, e113175. [CrossRef] [PubMed]

8. Antal, M.C.; Krust, A.; Chambon, P.; Mark, M. Sterility and absence of histopathological defects in nonreproductive organs of a mouse ERbeta-null mutant. Proc. Natl. Acad. Sci. USA 2008, 105, 2433-2438. [CrossRef]

9. Palmieri, C.; Cheng, G.J.; Saji, S.; Zelada-Hedman, M.; Warri, A.; Weihua, Z.; Van Noorden, S.; Wahlstrom, T.; Coombes, R.C.; Warner, M.; et al. Estrogen receptor beta in breast cancer. Endocr. Relat. Cancer 2002, 9, 1-13. [CrossRef]

10. Leygue, E.; Murphy, L.C. A bi-faceted role of estrogen receptor beta in breast cancer. Endocr. Relat. Cancer 2013, 20, R127-R139. [CrossRef]

11. Roger, P.; Sahla, M.E.; Mäkelä, S.; Gustafsson, J.Å.; Baldet, P.; Rochefort, H. Decreased expression of estrogen receptor $\beta$ protein in proliferative preinvasive mammary tumors. Cancer Res. 2001, 61, 2537-2541. [PubMed]

12. Järvinen, T.A.; Pelto-Huikko, M.; Holli, K.; Isola, J. Estrogen receptor $\beta$ is coexpressed with ER $\alpha$ and PR and associated with nodal status, grade, and proliferation rate in breast cancer. Am. J. Pathol. 2000, 156, 29-35. [CrossRef]

13. Shaaban, A.M.; O'Neill, P.A.; Davies, M.P.; Sibson, R.; West, C.R.; Smith, P.H.; Foster, C.S. Declining estrogen receptor- $\beta$ expression defines malignant progression of human breast neoplasia. Am. J. Surg. Pathol. 2003, 27, 1502-1512. [CrossRef] [PubMed]

14. Chantzi, N.I.; Palaiologou, M.; Stylianidou, A.; Goutas, N.; Vassilaros, S.; Kourea, H.P.; Dhimolea, E.; Mitsiou, D.J.; Tiniakos, D.G.; Alexis, M.N. Estrogen receptor $\beta 2$ is inversely correlated with Ki-67 in hyperplastic and noninvasive neoplastic breast lesions. J. Cancer Res. Clin. Oncol. 2014, 140, 1057-1066. [CrossRef] [PubMed]

15. Huang, B.; Omoto, Y.; Iwase, H.; Yamashita, H.; Toyama, T.; Coombes, R.C.; Filipovic, A.; Warner, M.; Gustafsson, J.- $\AA$. Differential expression of estrogen receptor $\alpha, \beta 1$, and $\beta 2$ in lobular and ductal breast cancer. Proc. Natl. Acad. Sci. USA 2014, 111, 1933-1938. [CrossRef]

16. Shaaban, A.M.; Jarvis, C.; Moore, F.; West, C.; Dodson, A.; Foster, C.S. Prognostic significance of estrogen receptor Beta in epithelial hyperplasia of usual type with known outcome. Am. J. Surg. Pathol. 2005, 29, 1593-1599. [CrossRef]

17. Prins, G.S.; Korach, K.S. The role of estrogens and estrogen receptors in normal prostate growth and disease. Steroids 2008, 73, 233-244. [CrossRef]

18. Bardin, A.; Boulle, N.; Lazennec, G.; Vignon, F.; Pujol, P. Loss of ER $\beta$ expression as a common step in estrogen-dependent tumor progression. Endocr. Relat. Cancer 2004, 11, 537-551. [CrossRef] [PubMed]

19. Zhao, C.; Lam, E.W.; Sunters, A.; Enmark, E.; De Bella, M.T.; Coombes, R.C.; Gustafsson, J.-Å.; Dahlman-Wright, K. Expression of estrogen receptor $\beta$ isoforms in normal breast epithelial cells and breast cancer: regulation by methylation. Oncogene 2003, 22, 7600-7606. [CrossRef]

20. Warner, M.; Wu, W.-F.; Montanholi, L.; Nalvarte, I.; Antonson, P.; Gustafsson, J.-A. Ventral prostate and mammary gland phenotype in mice with complete deletion of the ER $\beta$ gene. Proc. Natl. Acad. Sci. USA 2020, 117, 4902-4909. [CrossRef] 
21. Gustafsson, J.A.; Strom, A.; Warner, M. Update on ERbeta. J. Steroid Biochem. Mol. Biol. 2019, 191, 105312. [CrossRef] [PubMed]

22. Paris, O.; Ferraro, L.; Grober, O.M.; Ravo, M.; De Filippo, M.R.; Giurato, G.; Nassa, G.; Tarallo, R.; Cantarella, C.; Rizzo, F.; et al. Direct regulation of microRNA biogenesis and expression by estrogen receptor beta in hormone-responsive breast cancer. Oncogene 2012, 31, 4196-4206. [CrossRef]

23. Gruvberger-Saal, S.K.; Bendahl, P.O.; Saal, L.H.; Laakso, M.; Hegardt, C.; Eden, P.; Peterson, C.; Malmstrom, P.; Isola, J.; Borg, A.; et al. Estrogen receptor beta expression is associated with tamoxifen response in ERalpha-negative breast carcinoma. Clin. Cancer Res. 2007, 13, 1987-1994. [CrossRef]

24. Honma, N.; Horii, R.; Iwase, T.; Saji, S.; Younes, M.; Takubo, K.; Matsuura, M.; Ito, Y.; Akiyama, F.; Sakamoto, G. Clinical importance of estrogen receptor-beta evaluation in breast cancer patients treated with adjuvant tamoxifen therapy. J. Clin. Oncol. 2008, 26, 3727-3734. [CrossRef] [PubMed]

25. Fox, E.M.; Davis, R.J.; Shupnik, M.A. ER $\beta$ in breast cancer-Onlooker, passive player, or active protector? Steroids 2008, 73, 1039-1051. [CrossRef] [PubMed]

26. Leygue, E.; Murphy, L. Comparative evaluation of ERalpha and ERbeta significance in breast cancer: State of the art. Expert Rev. Endocrinol. Metab. 2011, 6, 333-343. [CrossRef] [PubMed]

27. Thomas, C.; Gustafsson, J.A. The different roles of ER subtypes in cancer biology and therapy. Nat. Rev. Cancer 2011, 11, 597-608. [CrossRef] [PubMed]

28. Leung, Y.-K.; Mak, P.; Hassan, S.; Ho, S.-M. Estrogen receptor (ER)- $\beta$ isoforms: A key to understanding ER- $\beta$ signaling. Proc. Natl. Acad. Sci. USA 2006, 103, 13162-13167. [CrossRef]

29. Murphy, L.C.; Leygue, E. The role of estrogen receptor- $\beta$ in breast cancer. Semin. Reprod. Med. 2012, 30, 5-13. [CrossRef]

30. Skliris, G.P.; Leygue, E.; Curtis-Snell, L.; Watson, P.H.; Murphy, L.C. Expression of oestrogen receptor-beta in oestrogen receptor-alpha negative human breast tumours. Br. J. Cancer 2006, 95, 616-626. [CrossRef]

31. Novelli, F.; Milella, M.; Melucci, E.; Di Benedetto, A.; Sperduti, I.; Perrone-Donnorso, R.; Perracchio, L.; Venturo, I.; Nistico, C.; Fabi, A.; et al. A divergent role for estrogen receptor-beta in node-positive and node-negative breast cancer classified according to molecular subtypes: An observational prospective study. Breast Cancer Res. 2008, 10, R74. [CrossRef] [PubMed]

32. Alexandrova, E.; Giurato, G.; Saggese, P.; Pecoraro, G.; Lamberti, J.; Ravo, M.; Rizzo, F.; Rocco, D.; Tarallo, R.; Nyman, T.A.; et al. Interaction Proteomics Identifies ERbeta Association with Chromatin Repressive Complexes to Inhibit Cholesterol Biosynthesis and Exert An Oncosuppressive Role in Triple-negative Breast Cancer. Mol. Cell Proteom. 2020, 19, 245-260. [CrossRef] [PubMed]

33. Austin, D.; Hamilton, N.; Elshimali, Y.; Pietras, R.; Wu, Y.; Vadgama, J. Estrogen receptor-beta is a potential target for triple negative breast cancer treatment. Oncotarget 2018, 9, 33912-33930. [CrossRef] [PubMed]

34. Skliris, G.P.; Leygue, E.; Watson, P.H.; Murphy, L.C. Estrogen receptor alpha negative breast cancer patients: Estrogen receptor beta as a therapeutic target. J. Steroid Biochem. Mol. Biol. 2008, 109, 1-10. [CrossRef]

35. Perou, C.M.; Sorlie, T.; Eisen, M.B.; van de Rijn, M.; Jeffrey, S.S.; Rees, C.A.; Pollack, J.R.; Ross, D.T.; Johnsen, H.; Akslen, L.A.; et al. Molecular portraits of human breast tumours. Nature 2000, 406, 747-752. [CrossRef]

36. Sorlie, T.; Perou, C.M.; Tibshirani, R.; Aas, T.; Geisler, S.; Johnsen, H.; Hastie, T.; Eisen, M.B.; van de Rijn, M.; Jeffrey, S.S.; et al. Gene expression patterns of breast carcinomas distinguish tumor subclasses with clinical implications. Proc. Natl. Acad. Sci. USA 2001, 98, 10869-10874. [CrossRef]

37. Reis-Filho, J.S.; Pusztai, L. Gene expression profiling in breast cancer: Classification, prognostication, and prediction. Lancet 2011, 378, 1812-1823. [CrossRef]

38. Rakha, E.A.; Reis-Filho, J.S.; Ellis, I.O. Combinatorial biomarker expression in breast cancer. Breast Cancer Res. Treat 2010, 120, 293-308. [CrossRef]

39. Tang, P.; Tse, G.M. Immunohistochemical Surrogates for Molecular Classification of Breast Carcinoma: A 2015 Update. Arch. Pathol. Lab. Med. 2016, 140, 806-814. [CrossRef]

40. Perou, C.M. Molecular stratification of triple-negative breast cancers. Oncologist 2011, 16, 61-70. [CrossRef]

41. Foulkes, W.D.; Smith, I.E.; Reis-Filho, J.S. Triple-negative breast cancer. N. Engl. J. Med. 2010, 363, 1938-1948. [CrossRef] [PubMed]

42. Morris, G.J.; Naidu, S.; Topham, A.K.; Guiles, F.; Xu, Y.; McCue, P.; Schwartz, G.F.; Park, P.K.; Rosenberg, A.L.; Brill, K.; et al. Differences in breast carcinoma characteristics in newly diagnosed African-American and Caucasian patients: A single-institution compilation compared with the National Cancer Institute's Surveillance, Epidemiology, and End Results database. Cancer 2007, 110, 876-884. [CrossRef] [PubMed] 
43. Rakha, E.A.; El-Sayed, M.E.; Green, A.R.; Lee, A.H.; Robertson, J.F.; Ellis, I.O. Prognostic markers in triple-negative breast cancer. Cancer 2007, 109, 25-32. [CrossRef] [PubMed]

44. Oakman, C.; Viale, G.; Di Leo, A. Management of triple negative breast cancer. Breast 2010, 19, $312-321$. [CrossRef] [PubMed]

45. Dent, R.; Trudeau, M.; Pritchard, K.I.; Hanna, W.M.; Kahn, H.K.; Sawka, C.A.; Lickley, L.A.; Rawlinson, E.; Sun, P.; Narod, S.A. Triple-negative breast cancer: Clinical features and patterns of recurrence. Clin. Cancer Res. 2007, 13, 4429-4434. [CrossRef]

46. Penault-Llorca, F.; Viale, G. Pathological and molecular diagnosis of triple-negative breast cancer: A clinical perspective. Ann. Oncol. 2012, 23, vi19-vi22. [CrossRef]

47. Wahba, H.A.; El-Hadaad, H.A. Current approaches in treatment of triple-negative breast cancer. Cancer Biol. Med. 2015, 12, 106-116. [CrossRef]

48. Anders, C.K.; Abramson, V.; Tan, T.; Dent, R. The Evolution of Triple-Negative Breast Cancer: From Biology to Novel Therapeutics. Am. Soc. Clin. Oncol. Educ. Book 2016, 35, 34-42. [CrossRef]

49. da Silva, J.L.; Cardoso Nunes, N.C.; Izetti, P.; de Mesquita, G.G.; de Melo, A.C. Triple negative breast cancer: A thorough review of biomarkers. Crit. Rev. Oncol. Hematol. 2020, 145, 102855. [CrossRef]

50. Mosselman, S.; Polman, J.; Dijkema, R. ER beta: Identification and characterization of a novel human estrogen receptor. FEBS Lett. 1996, 392, 49-53. [CrossRef]

51. Nilsson, S.; Gustafsson, J.A. Estrogen receptors: Therapies targeted to receptor subtypes. Clin. Pharmacol. Ther. 2011, 89, 44-55. [CrossRef] [PubMed]

52. Zhao, C.; Dahlman-Wright, K.; Gustafsson, J.A. Estrogen receptor beta: An overview and update. Nucl. Recept. Signal 2008, 6, e003. [CrossRef] [PubMed]

53. Pike, A.C.; Brzozowski, A.M.; Hubbard, R.E.; Bonn, T.; Thorsell, A.G.; Engstrom, O.; Ljunggren, J.; Gustafsson, J.A.; Carlquist, M. Structure of the ligand-binding domain of oestrogen receptor beta in the presence of a partial agonist and a full antagonist. EMBO J. 1999, 18, 4608-4618. [CrossRef] [PubMed]

54. Yan, Y.; Li, X.; Blanchard, A.; Bramwell, V.H.; Pritchard, K.I.; Tu, D.; Shepherd, L.; Myal, Y.; Penner, C.; Watson, P.H.; et al. Expression of both estrogen receptor-beta 1 (ER-beta1) and its co-regulator steroid receptor RNA activator protein (SRAP) are predictive for benefit from tamoxifen therapy in patients with estrogen receptor-alpha (ER-alpha)-negative early breast cancer (EBC). Ann. Oncol. 2013, 24, 1986-1993. [CrossRef]

55. Leung, Y.K.; Lee, M.T.; Lam, H.M.; Tarapore, P.; Ho, S.M. Estrogen receptor-beta and breast cancer: Translating biology into clinical practice. Steroids 2012, 77, 727-737. [CrossRef]

56. Haldosen, L.A.; Zhao, C.; Dahlman-Wright, K. Estrogen receptor beta in breast cancer. Mol. Cell. Endocrinol. 2014, 382, 665-672. [CrossRef]

57. Zhao, C.; Matthews, J.; Tujague, M.; Wan, J.; Strom, A.; Toresson, G.; Lam, E.W.; Cheng, G.; Gustafsson, J.A.; Dahlman-Wright, K. Estrogen receptor $\beta 2$ negatively regulates the transactivation of estrogen receptor alpha in human breast cancer cells. Cancer Res. 2007, 67, 3955-3962. [CrossRef]

58. Bozkurt, K.K.; Kapucuoglu, N. Investigation of immunohistochemical ERalpha, ERbeta and ERbetacx expressions in normal and neoplastic breast tissues. Pathol. Res. Pract. 2012, 208, 133-139. [CrossRef]

59. Girgert, R.; Emons, G.; Grundker, C. Estrogen Signaling in ERalpha-Negative Breast Cancer: ERbeta and GPER. Front. Endocrinol. 2018, 9, 781. [CrossRef]

60. Tong, D.; Schuster, E.; Seifert, M.; Czerwenka, K.; Leodolte, S.; Zeillinger, R. Expression of estrogen receptor beta isoforms in human breast cancer tissues and cell lines. Breast Cancer Res. Treat 2002, 71, $249-255$. [CrossRef]

61. Moore, J.T.; McKee, D.D.; Slentz-Kesler, K.; Moore, L.B.; Jones, S.A.; Horne, E.L.; Su, J.L.; Kliewer, S.A.; Lehmann, J.M.; Willson, T.M. Cloning and characterization of human estrogen receptor beta isoforms. Biochem. Biophys. Res. Commun. 1998, 247, 75-78. [CrossRef] [PubMed]

62. Chantzi, N.I.; Tiniakos, D.G.; Palaiologou, M.; Goutas, N.; Filippidis, T.; Vassilaros, S.D.; Dhimolea, E.; Mitsiou, D.J.; Alexis, M.N. Estrogen receptor $\beta 2$ is associated with poor prognosis in estrogen receptor alpha-negative breast carcinoma. J. Cancer Res. Clin. Oncol. 2013, 139, 1489-1498. [CrossRef] [PubMed]

63. Semenza, G.L. Hypoxia-inducible factors: Mediators of cancer progression and targets for cancer therapy. Trends Pharmacol. Sci. 2012, 33, 207-214. [CrossRef] [PubMed] 
64. Wimberly, H.; Han, G.; Pinnaduwage, D.; Murphy, L.C.; Yang, X.R.; Andrulis, I.L.; Sherman, M.; Figueroa, J.; Rimm, D.L. ERbeta splice variant expression in four large cohorts of human breast cancer patient tumors. Breast Cancer Res. Treat 2014, 146, 657-667. [CrossRef] [PubMed]

65. Wu, X.; Subramaniam, M.; Negron, V.; Cicek, M.; Reynolds, C.; Lingle, W.L.; Goetz, M.P.; Ingle, J.N.; Spelsberg, T.C.; Hawse, J.R. Development, characterization, and applications of a novel estrogen receptor beta monoclonal antibody. J. Cell. Biochem. 2012, 113, 711-723. [CrossRef]

66. Shanle, E.K.; Onitilo, A.A.; Huang, W.; Kim, K.; Zang, C.; Engel, J.M.; Xu, W.; Wisinski, K.B. Prognostic significance of full-length estrogen receptor beta expression in stage I-III triple negative breast cancer. Am. J. Transl. Res. 2015, 7, 1246-1259.

67. Andersson, S.; Sundberg, M.; Pristovsek, N.; Ibrahim, A.; Jonsson, P.; Katona, B.; Clausson, C.M.; Zieba, A.; Ramstrom, M.; Soderberg, O.; et al. Insufficient antibody validation challenges oestrogen receptor beta research. Nat. Commun. 2017, 8, 15840. [CrossRef]

68. Nelson, A.W.; Groen, A.J.; Miller, J.L.; Warren, A.Y.; Holmes, K.A.; Tarulli, G.A.; Tilley, W.D.; Katzenellenbogen, B.S.; Hawse, J.R.; Gnanapragasam, V.J.; et al. Comprehensive assessment of estrogen receptor beta antibodies in cancer cell line models and tissue reveals critical limitations in reagent specificity. Mol. Cell. Endocrinol. 2017, 440, 138-150. [CrossRef]

69. Tremblay, A.; Tremblay, G.B.; Labrie, F.; Giguère, V. Ligand-independent recruitment of SRC-1 to estrogen receptor $\beta$ through phosphorylation of activation function AF-1. Mol. Cell 1999, 3, 513-519. [CrossRef]

70. Ruff, M.; Gangloff, M.; Wurtz, J.M.; Moras, D. Estrogen receptor transcription and transactivation: Structure-function relationship in DNA- and ligand-binding domains of estrogen receptors. Breast Cancer Res. 2000, 2, 353-359. [CrossRef]

71. Patel, H.K.; Bihani, T. Selective estrogen receptor modulators (SERMs) and selective estrogen receptor degraders (SERDs) in cancer treatment. Pharmacol. Ther. 2018, 186, 1-24. [CrossRef] [PubMed]

72. Jordan, V.C. Tamoxifen: Catalyst for the change to targeted therapy. Eur. J. Cancer 2008, 44, 30-38. [CrossRef] [PubMed]

73. Kuiper, G.G.; Lemmen, J.G.; Carlsson, B.; Corton, J.C.; Safe, S.H.; van der Saag, P.T.; van der Burg, B.; Gustafsson, J.A. Interaction of estrogenic chemicals and phytoestrogens with estrogen receptor beta. Endocrinology 1998, 139, 4252-4263. [CrossRef] [PubMed]

74. Esslimani-Sahla, M.; Simony-Lafontaine, J.; Kramar, A.; Lavaill, R.; Mollevi, C.; Warner, M.; Gustafsson, J.-Å.; Rochefort, $H$. Estrogen receptor $\beta$ (ER $\beta$ ) level but not its ER $\beta c x$ variant helps to predict tamoxifen resistance in breast cancer. Clin. Cancer Res. 2004, 10, 5769-5776. [CrossRef] [PubMed]

75. Hopp, T.A.; Weiss, H.L.; Parra, I.S.; Cui, Y.; Osborne, C.K.; Fuqua, S.A. Low levels of estrogen receptor beta protein predict resistance to tamoxifen therapy in breast cancer. Clin. Cancer Res. 2004, 10, 7490-7499. [CrossRef] [PubMed]

76. Barkhem, T.; Carlsson, B.; Nilsson, Y.; Enmark, E.; Gustafsson, J.; Nilsson, S. Differential response of estrogen receptor alpha and estrogen receptor beta to partial estrogen agonists/antagonists. Mol. Pharmacol. 1998, 54, 105-112. [CrossRef] [PubMed]

77. Osborne, C.K.; Wakeling, A.; Nicholson, R.I. Fulvestrant: An oestrogen receptor antagonist with a novel mechanism of action. Br. J. Cancer 2004, 90, S2-S6. [CrossRef]

78. Howell, A.; Osborne, C.K.; Morris, C.; Wakeling, A.E. ICI 182,780 (Faslodex): Development of a novel, "pure" antiestrogen. Cancer 2000, 89, 817-825. [CrossRef]

79. Mishra, A.K.; Abrahamsson, A.; Dabrosin, C. Fulvestrant inhibits growth of triple negative breast cancer and synergizes with tamoxifen in ER $\alpha$ positive breast cancer by up-regulation of ER $\beta$. Oncotarget 2016, 7, 56876-56888. [CrossRef]

80. Minutolo, F.; Macchia, M.; Katzenellenbogen, B.S.; Katzenellenbogen, J.A. Estrogen receptor $\beta$ ligands: Recent advances and biomedical applications. Med. Res. Rev. 2011, 31, 364-442. [CrossRef]

81. Song, P.; Li, Y.; Dong, Y.; Liang, Y.; Qu, H.; Qi, D.; Lu, Y.; Jin, X.; Guo, Y.; Jia, Y.; et al. Estrogen receptor $\beta$ inhibits breast cancer cells migration and invasion through CLDN6-mediated autophagy. J. Exp. Clin. Cancer Res. 2019, 38, 354. [CrossRef] [PubMed]

82. Schüler-Toprak, S.; Häring, J.; Inwald, E.C.; Moehle, C.; Ortmann, O.; Treeck, O. Agonists and knockdown of estrogen receptor $\beta$ differentially affect invasion of triple-negative breast cancer cells in vitro. BMC Cancer 2016, 16, 951. [CrossRef] [PubMed] 
83. Reese, J.M.; Bruinsma, E.S.; Nelson, A.W.; Chernukhin, I.; Carroll, J.S.; Li, Y.; Subramaniam, M.; Suman, V.J.; Negron, V.; Monroe, D.G. ER $\beta$-mediated induction of cystatins results in suppression of TGF $\beta$ signaling and inhibition of triple-negative breast cancer metastasis. Proc. Natl. Acad. Sci. USA 2018, 115, E9580-E9589. [CrossRef] [PubMed]

84. Sareddy, G.R.; Li, X.; Liu, J.; Viswanadhapalli, S.; Garcia, L.; Gruslova, A.; Cavazos, D.; Garcia, M.; Strom, A.M.; Gustafsson, J.A.; et al. Selective Estrogen Receptor $\beta$ Agonist LY500307 as a Novel Therapeutic Agent for Glioblastoma. Sci. Rep. 2016, 6, 24185. [CrossRef]

85. Zhao, L.; Huang, S.; Mei, S.; Yang, Z.; Xu, L.; Zhou, N.; Yang, Q.; Shen, Q.; Wang, W.; Le, X.; et al. Pharmacological activation of estrogen receptor beta augments innate immunity to suppress cancer metastasis. Proc. Natl. Acad. Sci. USA 2018, 115, E3673-E3681. [CrossRef]

86. Sun, J.; Ma, X.; Chen, Y.X.; Rayner, K.; Hibbert, B.; McNulty, M.; Dhaliwal, B.; Simard, T.; Ramirez, D.; $\mathrm{O}^{\prime}$ Brien, E. Attenuation of atherogenesis via the anti-inflammatory effects of the selective estrogen receptor beta modulator 8ß-VE2. J. Cardiovasc. Pharmacol. 2011, 58, 399-405. [CrossRef]

87. Sareddy, G.R.; Vadlamudi, R.K. Cancer therapy using natural ligands that target estrogen receptor beta. Chin. J. Nat. Med. 2015, 13, 801-807. [CrossRef]

88. Mersereau, J.E.; Levy, N.; Staub, R.E.; Baggett, S.; Zogovic, T.; Zogric, T.; Chow, S.; Ricke, W.A.; Tagliaferri, M.; Cohen, I.; et al. Liquiritigenin is a plant-derived highly selective estrogen receptor beta agonist. Mol. Cell. Endocrinol. 2008, 283, 49-57. [CrossRef]

89. Middleton, E.; Kandaswami, C.; Theoharides, T.C. The effects of plant flavonoids on mammalian cells: Implications for inflammation, heart disease, and cancer. Pharmacol. Rev. 2000, 52, 673-751.

90. Hinsche, O.; Girgert, R.; Emons, G.; Gründker, C. Estrogen receptor $\beta$ selective agonists reduce invasiveness of triple-negative breast cancer cells. Int. J. Oncol. 2015, 46, 878-884. [CrossRef]

91. Pan, H.; Zhou, W.; He, W.; Liu, X.; Ding, Q.; Ling, L.; Zha, X.; Wang, S. Genistein inhibits MDA-MB-231 triple-negative breast cancer cell growth by inhibiting NF-kappaB activity via the Notch-1 pathway. Int. J. Mol. Med. 2012, 30, 337-343. [CrossRef] [PubMed]

92. Donovan, M.G.; Selmin, O.I.; Doetschman, T.C.; Romagnolo, D.F. Epigenetic Activation of BRCA1 by Genistein In Vivo and Triple Negative Breast Cancer Cells Linked to Antagonism toward Aryl Hydrocarbon Receptor. Nutrients 2019, 11, 2559. [CrossRef] [PubMed]

93. Setchell, K.D.; Clerici, C.; Lephart, E.D.; Cole, S.J.; Heenan, C.; Castellani, D.; Wolfe, B.E.; Nechemias-Zimmer, L.; Brown, N.M.; Lund, T.D.; et al. S-equol, a potent ligand for estrogen receptor beta, is the exclusive enantiomeric form of the soy isoflavone metabolite produced by human intestinal bacterial flora. Am. J. Clin. Nutr. 2005, 81, 1072-1079. [CrossRef] [PubMed]

94. Coriano, C.G.; Liu, F.; Sievers, C.K.; Liang, M.; Wang, Y.; Lim, Y.; Yu, M.; Xu, W. A Computational-Based Approach to Identify Estrogen Receptor alpha/beta Heterodimer Selective Ligands. Mol. Pharmacol. 2018, 93, 197-207. [CrossRef] [PubMed]

95. Park, B.-W.; Kim, K.-S.; Heo, M.-K.; Ko, S.-S.; Lee, K.S.; Hong, S.W.; Yang, W.-I.; Kim, J.-H.; Kim, G.E. Expression of estrogen receptor- $\beta$ in normal mammary and tumor tissues: Is it protective in breast carcinogenesis? Breast Cancer Res. Treat 2003, 80, 79-85. [CrossRef] [PubMed]

96. Speirs, V.; Malone, C.; Walton, D.S.; Kerin, M.J.; Atkin, S.L. Increased expression of estrogen receptor $\beta$ mRNA in tamoxifen-resistant breast cancer patients. Cancer Res. 1999, 59, 5421-5424.

97. Skliris, G.P.; Carder, P.J.; Lansdown, M.R.; Speirs, V. Immunohistochemical detection of ERbeta in breast cancer: Towards more detailed receptor profiling? Br. J. Cancer 2001, 84, 1095-1098. [CrossRef]

98. Tan, W.; Li, Q.; Chen, K.; Su, F.; Song, E.; Gong, C. Estrogen receptor beta as a prognostic factor in breast cancer patients: A systematic review and meta-analysis. Oncotarget 2016, 7, 10373-10385. [CrossRef]

99. Duong, B.N.; Elliott, S.; Frigo, D.E.; Melnik, L.I.; Vanhoy, L.; Tomchuck, S.; Lebeau, H.P.; David, O.; Beckman, B.S.; Alam, J.; et al. AKT regulation of estrogen receptor beta transcriptional activity in breast cancer. Cancer Res. 2006, 66, 8373-8381. [CrossRef]

100. Baek, J.M.; Chae, B.J.; Song, B.J.; Jung, S.S. The potential role of estrogen receptor beta2 in breast cancer. Int. J. Surg. 2015, 14, 17-22. [CrossRef] [PubMed]

101. Miller, W.R.; Anderson, T.J.; Dixon, J.M.; Saunders, P.T. Oestrogen receptor beta and neoadjuvant therapy with tamoxifen: Prediction of response and effects of treatment. Br. J. Cancer 2006, 94, 1333-1338. [CrossRef] [PubMed] 
102. Wang, J.; Zhang, C.; Chen, K.; Tang, H.; Tang, J.; Song, C.; Xie, X. ER $\beta 1$ inversely correlates with PTEN/PI3K/AKT pathway and predicts a favorable prognosis in triple-negative breast cancer. Breast Cancer Res. Treat 2015, 152, 255-269. [CrossRef] [PubMed]

103. Feitelson, M.A.; Arzumanyan, A.; Kulathinal, R.J.; Blain, S.W.; Holcombe, R.F.; Mahajna, J.; Marino, M.; Martinez-Chantar, M.L.; Nawroth, R.; Sanchez-Garcia, I.; et al. Sustained proliferation in cancer: Mechanisms and novel therapeutic targets. Semin. Cancer Biol. 2015, 35, S25-S54. [CrossRef] [PubMed]

104. Paruthiyil, S.; Parmar, H.; Kerekatte, V.; Cunha, G.R.; Firestone, G.L.; Leitman, D.C. Estrogen receptor beta inhibits human breast cancer cell proliferation and tumor formation by causing a G2 cell cycle arrest. Cancer Res. 2004, 64, 423-428. [CrossRef]

105. Lin, C.Y.; Strom, A.; Li Kong, S.; Kietz, S.; Thomsen, J.S.; Tee, J.B.; Vega, V.B.; Miller, L.D.; Smeds, J.; Bergh, J.; et al. Inhibitory effects of estrogen receptor beta on specific hormone-responsive gene expression and association with disease outcome in primary breast cancer. Breast Cancer Res. 2007, 9, R25. [CrossRef]

106. Behrens, D.; Gill, J.H.; Fichtner, I. Loss of tumourigenicity of stably ERbeta-transfected MCF-7 breast cancer cells. Mol. Cell. Endocrinol. 2007, 274, 19-29. [CrossRef]

107. Shanle, E.K.; Zhao, Z.; Hawse, J.; Wisinski, K.; Keles, S.; Yuan, M.; Xu, W. Research resource: Global identification of estrogen receptor beta target genes in triple negative breast cancer cells. Mol. Endocrinol. 2013, 27, 1762-1775. [CrossRef]

108. Jung, Y.S.; Park, J.I. Wnt signaling in cancer: Therapeutic targeting of Wnt signaling beyond beta-catenin and the destruction complex. Exp. Mol. Med. 2020, 52, 183-191. [CrossRef]

109. Otto, T.; Sicinski, P. Cell cycle proteins as promising targets in cancer therapy. Nat. Rev. Cancer 2017, 17, 93-115. [CrossRef]

110. Reese, J.M.; Suman, V.J.; Subramaniam, M.; Wu, X.; Negron, V.; Gingery, A.; Pitel, K.S.; Shah, S.S.; Cunliffe, H.E.; McCullough, A.E.; et al. ER $\beta 1$ : Characterization, prognosis, and evaluation of treatment strategies in ER $\alpha$-positive and -negative breast cancer. BMC Cancer 2014, 14, 749. [CrossRef]

111. Reese, J.M.; Bruinsma, E.S.; Monroe, D.G.; Negron, V.; Suman, V.J.; Ingle, J.N.; Goetz, M.P.; Hawse, J.R. ERbeta inhibits cyclin dependent kinases 1 and 7 in triple negative breast cancer. Oncotarget 2017, 8, 96506-96521. [CrossRef] [PubMed]

112. Thomas, C.G.; Strom, A.; Lindberg, K.; Gustafsson, J.-A. Estrogen receptor beta decreases survival of p53-defective cancer cells after DNA damage by impairing G 2/M checkpoint signaling. Breast Cancer Res. Treat 2011, 127, 417-427. [CrossRef] [PubMed]

113. Renoir, J.-M.; Marsaud, V.; Lazennec, G. Estrogen receptor signaling as a target for novel breast cancer therapeutics. Biochem. Pharmacol. 2013, 85, 449-465. [CrossRef] [PubMed]

114. Bado, I.; Nikolos, F.; Rajapaksa, G.; Gustafsson, J.-^̊.; Thomas, C. ER $\beta$ decreases the invasiveness of triple-negative breast cancer cells by regulating mutant p53 oncogenic function. Oncotarget 2016, 7, 13599. [CrossRef]

115. Thomas, C.; Rajapaksa, G.; Nikolos, F.; Hao, R.; Katchy, A.; McCollum, C.W.; Bondesson, M.; Quinlan, P.; Thompson, A.; Krishnamurthy, S. ER $\beta 1$ represses basal-like breast cancer epithelial to mesenchymal transition by destabilizing EGFR. Breast Cancer Res. 2012, 14, R148. [CrossRef]

116. Song, W.; Tang, L.; Xu, Y.; Sun, Q.; Yang, F.; Guan, X. ERß1 inhibits metastasis of androgen receptor-positive triple-negative breast cancer by suppressing ZEB1. J. Exp. Clin. Cancer Res. 2017, 36, 75. [CrossRef]

117. Moenner, M.; Pluquet, O.; Bouchecareilh, M.; Chevet, E. Integrated endoplasmic reticulum stress responses in cancer. Cancer Res. 2007, 67, 10631-10634. [CrossRef]

118. Walter, P.; Ron, D. The unfolded protein response: From stress pathway to homeostatic regulation. Science 2011, 334, 1081-1086. [CrossRef]

119. Tabas, I.; Ron, D. Integrating the mechanisms of apoptosis induced by endoplasmic reticulum stress. Nat. Cell Biol. 2011, 13, 184-190. [CrossRef]

120. Ma, Y.; Hendershot, L.M. The role of the unfolded protein response in tumour development: Friend or foe? Nat. Rev. Cancer 2004, 4, 966-977. [CrossRef]

121. Obacz, J.; Avril, T.; Le Reste, P.J.; Urra, H.; Quillien, V.; Hetz, C.; Chevet, E. Endoplasmic reticulum proteostasis in glioblastoma-From molecular mechanisms to therapeutic perspectives. Sci. Signal. 2017, 10. [CrossRef] [PubMed]

122. McGrath, E.P.; Logue, S.E.; Mnich, K.; Deegan, S.; Jäger, R.; Gorman, A.M.; Samali, A. The Unfolded Protein Response in Breast Cancer. Cancers 2018, 10, 344. [CrossRef] [PubMed] 
123. Rajapaksa, G.; Thomas, C.; Gustafsson, J. Estrogen signaling and unfolded protein response in breast cancer. J. Steroid Biochem. Mol. Biol. 2016, 163, 45-50. [CrossRef] [PubMed]

124. Clarke, R.; Shajahan, A.N.; Wang, Y.; Tyson, J.J.; Riggins, R.B.; Weiner, L.M.; Bauman, W.T.; Xuan, J.; Zhang, B.; Facey, C.; et al. Endoplasmic reticulum stress, the unfolded protein response, and gene network modeling in antiestrogen resistant breast cancer. Horm. Mol. Biol. Clin. Investig. 2011, 5, 35-44. [CrossRef] [PubMed]

125. Clarke, R.; Cook, K.L.; Hu, R.; Facey, C.O.; Tavassoly, I.; Schwartz, J.L.; Baumann, W.T.; Tyson, J.J.; Xuan, J.; Wang, Y.; et al. Endoplasmic reticulum stress, the unfolded protein response, autophagy, and the integrated regulation of breast cancer cell fate. Cancer Res. 2012, 72, 1321-1331. [CrossRef] [PubMed]

126. Lee, E.; Nichols, P.; Groshen, S.; Spicer, D.; Lee, A.S. GRP78 as potential predictor for breast cancer response to adjuvant taxane therapy. Int. J. Cancer 2011, 128, 726-731. [CrossRef]

127. Avril, T.; Vauléon, E.; Chevet, E. Endoplasmic reticulum stress signaling and chemotherapy resistance in solid cancers. Oncogenesis 2017, 6, e373. [CrossRef]

128. Kimata, Y.; Kohno, K. Endoplasmic reticulum stress-sensing mechanisms in yeast and mammalian cells. Curr. Opin. Cell Biol. 2011, 23, 135-142. [CrossRef]

129. Calfon, M.; Zeng, H.; Urano, F.; Till, J.H.; Hubbard, S.R.; Harding, H.P.; Clark, S.G.; Ron, D. IRE1 couples endoplasmic reticulum load to secretory capacity by processing the XBP-1 mRNA. Nature 2002, 415, 92-96. [CrossRef]

130. Yoshida, H.; Matsui, T.; Yamamoto, A.; Okada, T.; Mori, K. XBP1 mRNA is induced by ATF6 and spliced by IRE1 in response to ER stress to produce a highly active transcription factor. Cell 2001, 107, 881-891. [CrossRef]

131. Acosta-Alvear, D.; Zhou, Y.; Blais, A.; Tsikitis, M.; Lents, N.H.; Arias, C.; Lennon, C.J.; Kluger, Y.; Dynlacht, B.D. XBP1 controls diverse cell type- and condition-specific transcriptional regulatory networks. Mol. Cell 2007, 27, 53-66. [CrossRef] [PubMed]

132. Lee, A.H.; Iwakoshi, N.N.; Glimcher, L.H. XBP-1 regulates a subset of endoplasmic reticulum resident chaperone genes in the unfolded protein response. Mol. Cell. Biol. 2003, 23, 7448-7459. [CrossRef] [PubMed]

133. Jiang, D.; Turner, B.; Song, J.; Li, R.; Diehn, M.; Le, Q.T.; Khatri, P.; Koong, A.C. Comprehensive Analysis of the Unfolded Protein Response in Breast Cancer Subtypes. JCO Precis. Oncol. 2017, 2017. [CrossRef] [PubMed]

134. Chen, X.; Iliopoulos, D.; Zhang, Q.; Tang, Q.; Greenblatt, M.B.; Hatziapostolou, M.; Lim, E.; Tam, W.L.; Ni, M.; Chen, Y.; et al. XBP1 promotes triple-negative breast cancer by controlling the HIF1 $\alpha$ pathway. Nature 2014, 508, 103-107. [CrossRef]

135. Idowu, M.O.; Kmieciak, M.; Dumur, C.; Burton, R.S.; Grimes, M.M.; Powers, C.N.; Manjili, M.H. CD44(+)/CD24(-/low) cancer stem/progenitor cells are more abundant in triple-negative invasive breast carcinoma phenotype and are associated with poor outcome. Hum. Pathol. 2012, 43, 364-373. [CrossRef]

136. Lin, Y.; Zhong, Y.; Guan, H.; Zhang, X.; Sun, Q. CD44+/CD24- phenotype contributes to malignant relapse following surgical resection and chemotherapy in patients with invasive ductal carcinoma. J. Exp. Clin. Cancer Res. 2012, 31, 59. [CrossRef] [PubMed]

137. Creighton, C.J.; Li, X.; Landis, M.; Dixon, J.M.; Neumeister, V.M.; Sjolund, A.; Rimm, D.L.; Wong, H.; Rodriguez, A.; Herschkowitz, J.I.; et al. Residual breast cancers after conventional therapy display mesenchymal as well as tumor-initiating features. Proc. Natl. Acad. Sci. USA 2009, 106, 13820-13825. [CrossRef]

138. Montagner, M.; Enzo, E.; Forcato, M.; Zanconato, F.; Parenti, A.; Rampazzo, E.; Basso, G.; Leo, G.; Rosato, A.; Bicciato, S.; et al. SHARP1 suppresses breast cancer metastasis by promoting degradation of hypoxia-inducible factors. Nature 2012, 487, 380-384. [CrossRef]

139. Network, C.G.A. Comprehensive molecular portraits of human breast tumours. Nature 2012, 490, 61-70. [CrossRef]

140. Rajapaksa, G.; Nikolos, F.; Bado, I.; Clarke, R.; Gustafsson, J.; Thomas, C. ER $\beta$ decreases breast cancer cell survival by regulating the IRE1/XBP-1 pathway. Oncogene 2015, 34, 4130-4141. [CrossRef]

141. Gao, B.; Lee, S.M.; Chen, A.; Zhang, J.; Zhang, D.D.; Kannan, K.; Ortmann, R.A.; Fang, D. Synoviolin promotes IRE1 ubiquitination and degradation in synovial fibroblasts from mice with collagen-induced arthritis. EMBO Rep. 2008, 9, 480-485. [CrossRef] [PubMed] 
142. Marcu, M.G.; Doyle, M.; Bertolotti, A.; Ron, D.; Hendershot, L.; Neckers, L. Heat shock protein 90 modulates the unfolded protein response by stabilizing IRE1alpha. Mol. Cell. Biol. 2002, 22, 8506-8513. [CrossRef] [PubMed]

143. Gustafsson, C.M.; Falkenberg, M.; Larsson, N.G. Maintenance and Expression of Mammalian Mitochondrial DNA. Annu. Rev. Biochem. 2016, 85, 133-160. [CrossRef] [PubMed]

144. Koppenol, W.H.; Bounds, P.L.; Dang, C.V. Otto Warburg's contributions to current concepts of cancer metabolism. Nat. Rev. Cancer 2011, 11, 325-337. [CrossRef] [PubMed]

145. Zheng, J. Energy metabolism of cancer: Glycolysis versus oxidative phosphorylation (Review). Oncol. Lett. 2012, 4, 1151-1157. [CrossRef] [PubMed]

146. Yeung, S.J.; Pan, J.; Lee, M.H. Roles of p53, MYC and HIF-1 in regulating glycolysis-The seventh hallmark of cancer. Cell. Mol. Life Sci. 2008, 65, 3981-3999. [CrossRef]

147. DeBerardinis, R.J.; Lum, J.J.; Hatzivassiliou, G.; Thompson, C.B. The biology of cancer: Metabolic reprogramming fuels cell growth and proliferation. Cell Metab. 2008, 7, 11-20. [CrossRef]

148. Kim, S.; Kim, D.H.; Jung, W.H.; Koo, J.S. Metabolic phenotypes in triple-negative breast cancer. Tumour Biol. 2013, 34, 1699-1712. [CrossRef]

149. Lanning, N.J.; Castle, J.P.; Singh, S.J.; Leon, A.N.; Tovar, E.A.; Sanghera, A.; MacKeigan, J.P.; Filipp, F.V.; Graveel, C.R. Metabolic profiling of triple-negative breast cancer cells reveals metabolic vulnerabilities. Cancer Metab. 2017, 5, 6. [CrossRef] [PubMed]

150. Wahdan-Alaswad, R.; Fan, Z.; Edgerton, S.M.; Liu, B.; Deng, X.S.; Arnadottir, S.S.; Richer, J.K.; Anderson, S.M.; Thor, A.D. Glucose promotes breast cancer aggression and reduces metformin efficacy. Cell Cycle 2013, 12, 3759-3769. [CrossRef]

151. Palorini, R.; Simonetto, T.; Cirulli, C.; Chiaradonna, F. Mitochondrial complex I inhibitors and forced oxidative phosphorylation synergize in inducing cancer cell death. Int. J. Cell Biol. 2013, 2013, 243876. [CrossRef] [PubMed]

152. Gründker, C.; Wokoun, U.; Hellriegel, M.; Emons, G. Inhibition of aerobic glycolysis enhances the anti-tumor efficacy of Zoptarelin Doxorubicin in triple-negative breast cancer cells. J Obstet. Gynaecol. Res. 2019, 45, 1334-1342. [CrossRef] [PubMed]

153. Yang, S.H.; Liu, R.; Perez, E.J.; Wen, Y.; Stevens, S.M.; Valencia, T.; Brun-Zinkernagel, A.M.; Prokai, L.; Will, Y.; Dykens, J.; et al. Mitochondrial localization of estrogen receptor beta. Proc. Natl. Acad. Sci. USA 2004, 101, 4130-4135. [CrossRef] [PubMed]

154. Psarra, A.M.; Sekeris, C.E. Steroid and thyroid hormone receptors in mitochondria. IUBMB Life 2008, 60, 210-223. [CrossRef]

155. Simpkins, J.W.; Yang, S.H.; Sarkar, S.N.; Pearce, V. Estrogen actions on mitochondria—Physiological and pathological implications. Mol. Cell. Endocrinol. 2008, 290, 51-59. [CrossRef]

156. Song, I.S.; Jeong, Y.J.; Jeong, S.H.; Kim, J.E.; Han, J.; Kim, T.H.; Jang, S.W. Modulation of Mitochondrial ER $\beta$ Expression Inhibits Triple-Negative Breast Cancer Tumor Progression by Activating Mitochondrial Function. Cell Physiol. Biochem. 2019, 52, 468-485. [CrossRef]

157. Chen, J.Q.; Delannoy, M.; Cooke, C.; Yager, J.D. Mitochondrial localization of ERalpha and ERbeta in human MCF7 cells. Am. J. Physiol. Endocrinol. Metab. 2004, 286, E1011-E1022. [CrossRef]

158. Grober, O.M.; Mutarelli, M.; Giurato, G.; Ravo, M.; Cicatiello, L.; De Filippo, M.R.; Ferraro, L.; Nassa, G.; Papa, M.F.; Paris, O.; et al. Global analysis of estrogen receptor beta binding to breast cancer cell genome reveals an extensive interplay with estrogen receptor alpha for target gene regulation. BMC Genom. 2011, 12, 36. [CrossRef]

159. Chen, J.Q.; Yager, J.D. Estrogen's effects on mitochondrial gene expression: Mechanisms and potential contributions to estrogen carcinogenesis. Ann. N. Y. Acad. Sci. 2004, 1028, 258-272. [CrossRef]

160. Riscal, R.; Skuli, N.; Simon, M.C. Even Cancer Cells Watch Their Cholesterol! Mol. Cell 2019, 76, $220-231$. [CrossRef]

161. Kuzu, O.F.; Noory, M.A.; Robertson, G.P. The Role of Cholesterol in Cancer. Cancer Res. 2016, 76, $2063-2070$. [CrossRef] [PubMed]

162. Ikonen, E. Cellular cholesterol trafficking and compartmentalization. Nat. Rev. Mol. Cell Biol. 2008, 9, 125-138. [CrossRef] [PubMed]

163. Payne, A.H.; Hales, D.B. Overview of steroidogenic enzymes in the pathway from cholesterol to active steroid hormones. Endocr. Rev. 2004, 25, 947-970. [CrossRef] 
164. Freed-Pastor, W.A.; Mizuno, H.; Zhao, X.; Langerød, A.; Moon, S.H.; Rodriguez-Barrueco, R.; Barsotti, A.; Chicas, A.; Li, W.; Polotskaia, A.; et al. Mutant p53 disrupts mammary tissue architecture via the mevalonate pathway. Cell 2012, 148, 244-258. [CrossRef]

165. Sorrentino, G.; Ruggeri, N.; Specchia, V.; Cordenonsi, M.; Mano, M.; Dupont, S.; Manfrin, A.; Ingallina, E.; Sommaggio, R.; Piazza, S.; et al. Metabolic control of YAP and TAZ by the mevalonate pathway. Nat. Cell Biol. 2014, 16, 357-366. [CrossRef] [PubMed]

166. Horton, J.D.; Goldstein, J.L.; Brown, M.S. SREBPs: Activators of the complete program of cholesterol and fatty acid synthesis in the liver. J. Clin. Investig. 2002, 109, 1125-1131. [CrossRef] [PubMed]

167. Brown, M.S.; Goldstein, J.L. The SREBP pathway: Regulation of cholesterol metabolism by proteolysis of a membrane-bound transcription factor. Cell 1997, 89, 331-340. [CrossRef]

168. Cai, D.; Wang, J.; Gao, B.; Li, J.; Wu, F.; Zou, J.X.; Xu, J.; Jiang, Y.; Zou, H.; Huang, Z.; et al. ROR $\gamma$ is a targetable master regulator of cholesterol biosynthesis in a cancer subtype. Nat. Commun. 2019, 10, 4621. [CrossRef]

169. Cai, D.; Zhang, X.; Chen, H.W. A master regulator of cholesterol biosynthesis constitutes a therapeutic liability of triple negative breast cancer. Mol. Cell. Oncol. 2020, 7, 1701362. [CrossRef]

170. Shah, S.P.; Roth, A.; Goya, R.; Oloumi, A.; Ha, G.; Zhao, Y.; Turashvili, G.; Ding, J.; Tse, K.; Haffari, G.; et al. The clonal and mutational evolution spectrum of primary triple-negative breast cancers. Nature 2012, 486, 395-399. [CrossRef]

171. Alexandrova, E.; Lamberti, J.; Saggese, P.; Pecoraro, G.; Memoli, D.; Cappa, V.M.; Ravo, M.; Iorio, R.; Tarallo, R.; Rizzo, F.; et al. Small Non-Coding RNA Profiling Identifies miR-181a-5p as a Mediator of Estrogen Receptor Beta-Induced Inhibition of Cholesterol Biosynthesis in Triple-Negative Breast Cancer. Cells 2020, 9, 874. [CrossRef] [PubMed]

172. Doane, A.S.; Danso, M.; Lal, P.; Donaton, M.; Zhang, L.; Hudis, C.; Gerald, W. An estrogen receptor-negative breast cancer subset characterized by a hormonally regulated transcriptional program and response to androgen. Oncogene 2006, 25, 3994-4008. [CrossRef] [PubMed]

173. Farmer, P.; Bonnefoi, H.; Becette, V.; Tubiana-Hulin, M.; Fumoleau, P.; Larsimont, D.; MacGrogan, G.; Bergh, J.; Cameron, D.; Goldstein, D. Identification of molecular apocrine breast tumours by microarray analysis. Breast Cancer Res. 2005, 7, 2-11. [CrossRef]

174. Cochrane, D.R.; Bernales, S.; Jacobsen, B.M.; Cittelly, D.M.; Howe, E.N.; D'Amato, N.C.; Spoelstra, N.S.; Edgerton, S.M.; Jean, A.; Guerrero, J. Role of the androgen receptor in breast cancer and preclinical analysis of enzalutamide. Breast Cancer Res. 2014, 16, R7. [CrossRef]

175. Gucalp, A.; Tolaney, S.; Isakoff, S.J.; Ingle, J.N.; Liu, M.C.; Carey, L.A.; Blackwell, K.; Rugo, H.; Nabell, L.; Forero, A. Phase II trial of bicalutamide in patients with androgen receptor-positive, estrogen receptor-negative metastatic breast cancer. Clin. Cancer Res. 2013, 19, 5505-5512. [CrossRef]

176. Traina, T.A.; Miller, K.; Yardley, D.A.; Eakle, J.; Schwartzberg, L.S.; O'Shaughnessy, J.; Gradishar, W.; Schmid, P.; Winer, E.; Kelly, C.; et al. Enzalutamide for the Treatment of Androgen Receptor-Expressing Triple-Negative Breast Cancer. J. Clin. Oncol. 2018, 36, 884-890. [CrossRef]

177. Anestis, A.; Sarantis, P.; Theocharis, S.; Zoi, I.; Tryfonopoulos, D.; Korogiannos, A.; Koumarianou, A.; Xingi, E.; Thomaidou, D.; Kontos, M.; et al. Estrogen receptor beta increases sensitivity to enzalutamide in androgen receptor-positive triple-negative breast cancer. J. Cancer Res. Clin. Oncol. 2019, 145, 1221-1233. [CrossRef]

178. Rampurwala, M.M.; Rocque, G.B.; Burkard, M.E. Update on adjuvant chemotherapy for early breast cancer. Breast Cancer 2014, 8, 125-133. [CrossRef]

179. Gucalp, A.; Traina, T.A. Targeting the androgen receptor in triple-negative breast cancer. Curr. Probl. Cancer 2016, 40, 141-150. [CrossRef]

180. Bianchini, G.; Balko, J.M.; Mayer, I.A.; Sanders, M.E.; Gianni, L. Triple-negative breast cancer: Challenges and opportunities of a heterogeneous disease. Nat. Rev. Clin. Oncol. 2016, 13, 674-690. [CrossRef]

181. Treiman, M.; Caspersen, C.; Christensen, S.B. A tool coming of age: Thapsigargin as an inhibitor of sarco-endoplasmic reticulum Ca(2+)-ATPases. Trends Pharmacol. Sci. 1998, 19, 131-135. [CrossRef]

182. Sato, K.; Rajendra, E.; Ohta, T. The UPS: A promising target for breast cancer treatment. BMC Biochem. 2008, 9, S2. [CrossRef] [PubMed] 
183. Beckwitt, C.H.; Brufsky, A.; Oltvai, Z.N.; Wells, A. Statin drugs to reduce breast cancer recurrence and mortality. Breast Cancer Res. 2018, 20, 144. [CrossRef] [PubMed]

184. Endo, A. A historical perspective on the discovery of statins. Proc. Jpn. Acad. 2010, 86, 484-493. [CrossRef]

(C) 2020 by the authors. Licensee MDPI, Basel, Switzerland. This article is an open access article distributed under the terms and conditions of the Creative Commons Attribution (CC BY) license (http://creativecommons.org/licenses/by/4.0/). 